\title{
Biofertilizer Impacts on Cassava (Manihot Esculenta Crantz) Rhizosphere: Crop Yield and Growth Components, Igbariam, Nigeria - Paper 1
}

\author{
Ayodele A Otaiku ${ }^{1 *}$, Mmom $\mathrm{PC}^{2}$ and Ano $\mathrm{A0}^{3}$ \\ ${ }^{1}$ Doctoral Student, Faculty of Social Science, Department of Geography and Environmental Management, University of Port Harcourt, Rivers State, Nigeria \\ ${ }^{2}$ Faculty of Social Science, Department of Geography and Environmental Management, University of Port Harcourt, Choba, Port Harcourt, Rivers State, Nigeria \\ ${ }^{3}$ National Root Crops Research Institute, Umudike Umuahia, Abia State, Nigeria
}

*Corresponding author: Ayodele A Otaiku, Doctoral Student, Faculty of Social Science, Department of Geography and Environmental Management, University of Port Harcourt, Choba, Port Harcourt, Rivers State, Nigeria.

Received Date: November 21, 2019

Published Date: November 27, 2019

\begin{abstract}
The impacts of biofertilizer (OBD) on cassava rhizosphere microbiome holistic soil function produced from anaerobic bio-digested from biowaste inoculated with beneficial microbes applied alone and in commination to cassava cultivation under rainfed conditions with inorganic fertilizer NPK (15:15:15) on an Ultisol soil Igbariam, Nigeria in 2012/2013 cropping seasons to determine the crop yield and growth components. Cassava stakes each measuring about $25 \mathrm{~cm}$ was then planted at $1 \mathrm{~m} \times 1 \mathrm{~m}$ spacing on top of the ridges. The treatments were arranged in a randomized complete block design replicated three times OBD-Biofertilizer in combination with NPK gave significantly higher cassava root yield $(\mathrm{P}<0.05)$ than the control. Application of recommended dose of NPK fertilizers along with biofertilizer resulted in significantly higher growth attributes in addition to dry matter production and tuber yield. With application of biofertilizer to low marginal soils for cultivation of cassava, the macronutrients and micronutrients enhanced by biofertilizer microbial inoculants that transforms roots development, photosynthetic rate, replenished extracted soil nutrients by cassava harvest and improved nitrogen use efficiency. Biofertilizer can improve highly weathered and leached Oxisols, Ultisols and Alfisols soils where cassava is cultivated in the tropics and mitigate environment degradation. Biofertilizer applied cassava production soil provides interactions produces stability and resilience of soil with respect to functional characteristics. The trilogy papers illuminate the biofertilizer impacts on the functions of rhizosphere microbiome on cassava crop cultivation, development and protection (Graphical Abstract).
\end{abstract}
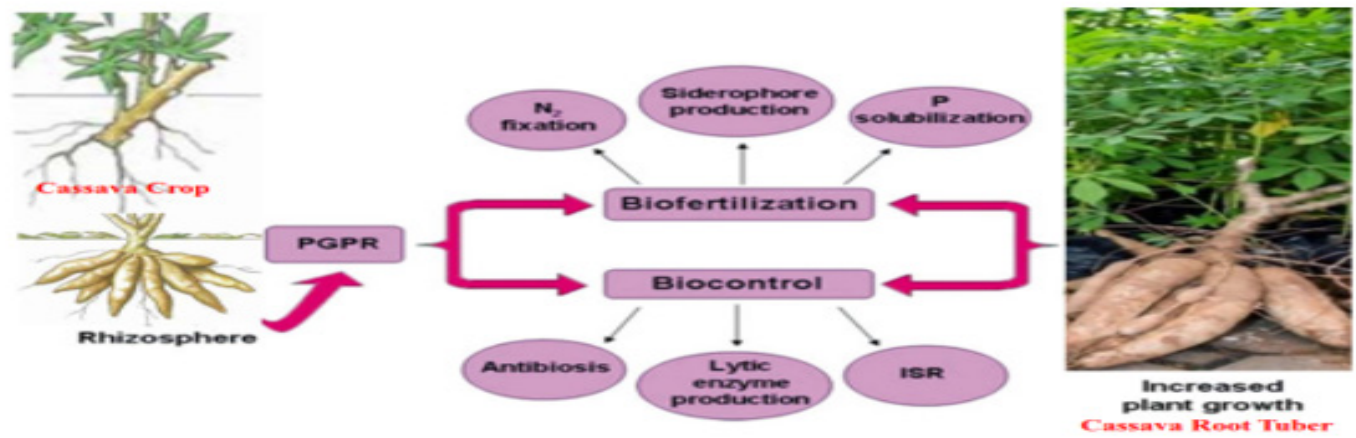

Keywords: Crop yield; Bio-waste; Biofertilizer; Inoculants; Bacterial endophyte; Inorganic fertilizer; Cassava (Manihot esculenta crantz); Photosynthetic rate; Rhizosphere microbiome

\section{Introduction}

Cassava (Manihot esculenta crantz) is a perennial shrub grown principally for its starchy roots which are used as food, animal feed and as a source of starch. Cassava tends to be grown on the poorer

agricultural lands, without irrigation and with limited application of purchased inputs. It is naturally well adapted to these conditions [1]. Nevertheless, the tremendous variation in conditions to 
which it is subjected means that cassava production technology needs to be adapted to the varying natural conditions, rather than using costly modifications of the environment to suit a particular production system [2]. An understanding of the manner in which the crop responds to varying environmental conditions is an essential component of designing improved low-input technologies like biofertilizer, well adapted to the particular conditions where individual farmers grow their crops. The cassava crop is essentially grown between $300 \mathrm{~S}$ and $300 \mathrm{~N}$ latitude of the globe. As the crop moves further north or south of the equator the maximum altitude at which it grows and produces will decrease. The crop is generally not found in areas where the mean average temperature is less than about $20{ }^{\circ} \mathrm{C}$, although in areas near the equator where seasonal temperature fluctuations are small it can be found growing in areas with a mean temperature as low as $17^{\circ} \mathrm{C}[3]$.

To increase the yield potential of cassava, the crop has been reported to respond to good soil fertility and adequate fertilizer [4]. The major nutrients required by cassava for optimum top growth and tuber yields are nitrogen $(\mathrm{N})$ and potassium $(\mathrm{K})$. Soils that have low $\mathrm{N}(<0.10 \%$ total $\mathrm{N})$ and $\mathrm{K}(<0.15 \mathrm{meg} / 100 \mathrm{~g})$ will require an additional fertilizer for optimum tuber yield [5]. Adequate $\mathrm{K}$ levels in the soil stimulate the response to $\mathrm{N}$ fertilizers, but excess amount of both nutrient leads to luxuriant growth at the expense of tuber formation [6]. Cropping systems influence fertilizer requirements of cassava; for example, the continuous cropping of cassava leads to fast depletion of major nutrients, especially $\mathrm{N}$ and $\mathrm{K}$ and will require fertilizer supplement to give stable yield. Cassava removes about $55 \mathrm{~kg} / \mathrm{ha} \mathrm{N}, 132 \mathrm{~kg} / \mathrm{ha} \mathrm{P}$ and $112 \mathrm{~kg} / \mathrm{ha} \mathrm{K}$ reported by [7].

\section{Cassava Improvement and Biotechnology}

However, farmers rarely use chemical fertilizer due to scarcity and cost, hence the dependence on cheap organic sources of nutrients. These reasons necessitate research on increasing effectiveness of organic manures and suitable rate of application. The effect of digester effluent was compared with pig and cattle manure [8] and it was found that bio-digester effluent gave higher biomers, yield and protein content of cassava. These necessitate the biofertilizer research production using agriculture wastesinoculated with broad spectrum microorganism accelerated composed in an anaerobic bio digester. One of the factors responsible for low yield is declining soil fertility. In the past, soil fertility has been sustained through long fallowing [9]. When biofertilizers applied as soil inoculants, they multiply and participate in nutrient cycling and benefit crop productivity [10]. OBD-Biofertilizer composted using anaerobic bio-digester technology (https://www.youtube.com/ watch? v=Hi_OpgVcFcg biofertilizer) from bio-waste in anaerobic digester inoculated with beneficial microbes that exhibit differing metabolic capabilities.

Biotechnology tools have been adapted to cassava and are currently incorporated in different projects for its genetic improvement. A molecular map has been developed [11,12] and marker-assisted selection is currently used for key traits [13]. Molecular markers that allow selection of segregating progenies that carry the resistance of Cassava Mosaic Disease (CMD) have been successfully utilized [13]. A molecular genetic map has been developed for cassava [12] where cassava genetic improvement can be made more efficient through the use of easily assayable molecular genetic or DNA markers (MAS) that enable the precise identification of genotype without the confounding effect of the environment; in other words, increasing heritability.

Genetic transformation protocols are available and have been used successfully for the incorporation of different genes [14]. As the crop has evolved and new improved varieties that satisfy the most important needs have been released and adopted by farmers, new challenges and opportunities arise. An important need is to introduce herbicide tolerance in the crop. Several approaches can be taken from genetic transformation [15], to screening for the natural occurrence of tolerance to certain herbicides, to the induction of mutations as already demonstrated for different herbicides and different crops [16]. The lack of genetic variability for overcoming the problem of post-harvest physiological deterioration remains a major bottleneck for cassava utilization and commercialization, although significant breakthroughs have been achieved recently.

Systemic Approach for Sustainable Agriculture Delivering food security and improving food quality to sustain population growth without compromising environmental safety is global benchmark for green revolution [17]. The beneficial effects and mechanisms of microbes on plant health and fitness and their utilization in agriculture are widely studied and documented [1823]. The rhizosphere is the interface between roots and the soil where nutrient absorption for plant growth in agroecosystems is facilitated. Carbon flows from the plant to the soil ecosystem as simple organic compounds providing the necessary food basis for the corresponding microbiological processes that are vital for soil ecosystem functioning [24]. Both plant beneficial microorganisms (plant growth promoters and biocontrol agents) and pests (root pathogens and root feeding insects) are common inhabitants of the rhizosphere [25], all affecting $\mathrm{C}, \mathrm{N}$ and $\mathrm{P}$ biogeochemical processes in the soil. Functional traits of the beneficial rhizosphere microbiome in relation to plant nutrition and health include organic matter decomposition, $\mathrm{P}$ solubilization and transport, $\mathrm{N}$ fixation and biocontrol of root pests [26]. Biological indicators in the past stressed management effects on biodiversity, e.g., were conservation oriented, but recent developments emphasize methods indicating soil functions and general soil health [27-30]. These different approaches reflect the obvious interrelations between physical, chemical and biological agents in the soil systems.

\section{Biofertilizer}

A key merit of microorganisms is to assimilate phosphorus for their own requirement, which in turn available as its soluble form in sufficient quantities in soil. Pseudomonas, Bacillus, Micrococcus, Flavobacterium, Fusarium, Sclerotium, Aspergillus and Penicillium have been reported to be active in the solubilization process [31].

A phosphate-solubilizing bacterial strain Micrococcus sp. has polyvalent properties including phosphate solubilization 
and siderophore production [32]. Similarly, two fungi Aspergillus fumigatus and Aspergillus Niger were isolated from decaying cassava peels were found to convert cassava wastes by the semisolid fermentation technique to phosphate biofertilizers [33] Burkholderia vietnamiensis, stress tolerant bacteria, produces gluconic and 2-ketogluconic acids, which involved in phosphate solubilization. Potassium solubilizing microorganisms (KSM) such as genus Aspergillus, Bacillus and Clostridium are found to be efficient in potassium solubilization in the soil and mobilize in different crops [34]. Mycorrhizal mutualistic symbiosis with plant roots satisfies the plant nutrients demand [35] which leads to the enhancement plant growth and 'development and protect plants from pathogens attack and environmental stress Figure 1. Pseudomonas aeruginosa has been shown to withstand biotic and abiotic stresses [31]. Paul and Nair [36] found that P. fluorescens MSP-393 produces osmolytes and salt-stress induced proteins that overcome the negative effects of salt. Microbial inoculants genera in the OBD-Biofertilizer are isolated using the growth media in Table 1 from different agro biowaste and inoculated into the composted biofertilizer (Plant Growth-Promoting Rhizobacteria. Microorganisms, PGPRs) Table 2.

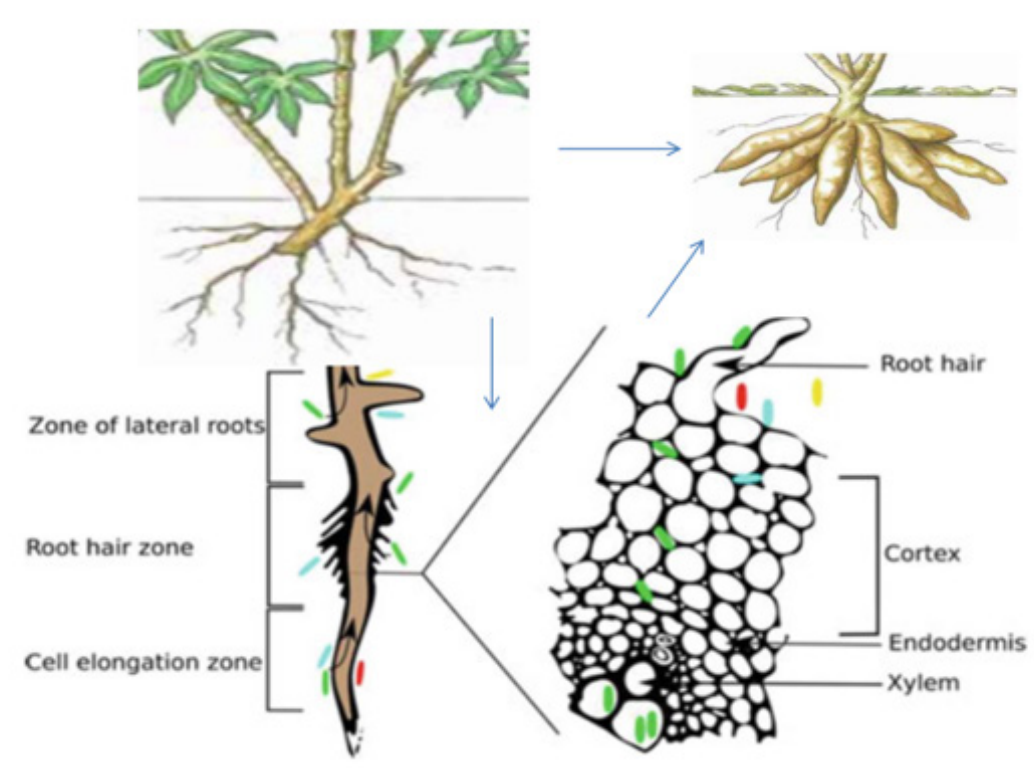

Figure 1: Endophytic bacterial colonization in cassava plants modelled. Bacteria can enter a plant at several root zones as indicated above. Endophytes can either remain at the site of entry (indicated in blue) or move deeper inside or occupy the intercellular space of the cortex and xylem vessels (indicated in green). Red and yellow represent rhizospheric bacteria which are unable to colonize inner plant tissues adapted from Maheshwari \& Annapurna [138].

Table 1: Microbial culture techniques of beneficial microorganisms presents in OBD-Biofertilizer.

\begin{tabular}{|c|c|c|c|}
\hline S.N. & Growth Media & Microbes & References \\
\hline 1 & Ammonium mineral salt & Methylotrophs & Holland et al. (2000) \\
\hline 2 & Congo red yeast mannitol & Rhizobium & Yumoto et al. (2002) \\
\hline 3 & DSMZ-97, DSMZ-823, DSMZ-1184; OS & Halophilic archaea & Yadav et al. (2015c) \\
\hline 4 & Jensen agar & N2-fixing bacteria & Jensen (1965) \\
\hline 5 & King's Bagar & Pseudomonas sp. & Mishra et al. (2009) \\
\hline 6 & Luria Bentosa et al. (1982) \\
\hline 7 & Nutrient agar & Endophytic bacteria & Ramesh and Lonsane (1987) \\
\hline 8 & Potato dextrose agar & Fungus & Sehgal and Gibbons (1960) \\
\hline 9 & Soil extract agar & Soil-specific microbes & Shivaji et al. (1988) \\
\hline 10 & Tryptic soy agar & Arthrobacter & Shivaji et al. (1989) \\
\hline
\end{tabular}

Table 2: PGPRs Biosurfactants presents in OTAI AG ${ }^{\circledR}$ Inocula with literature references.

\begin{tabular}{|c|c|c|c|c|}
\hline N/S & Biosurfactants & Microorganisms & Economic Importance & References \\
\hline 1 & Rhamnolipids & Pseudomonas aeruginosa & Antimicrobial & Jadhav, et al. [128] \\
\hline & & & biocontrol properties & Banat, et al. [114] \\
\hline 2 & Viscosin & Pseudomonas fluorescens & Bio-emulsifiers & Desai \& Banat [120] \\
\hline 3 & Ornithine lipids & Agrobacterium sp. & Bio-emulsifiers & \\
\hline & & Pseudomonas sp. & & \\
\hline
\end{tabular}




\begin{tabular}{|c|c|c|c|c|}
\hline & & Thiobacillus thiooxidans & Bio-emulsifiers & \\
\hline 4 & Carbohydratel Liipid & Pfluorescens & Bio-emulsifiers & Nerurka, et al. [140] \\
\hline 5 & Protein PA & Paeruginosa & Bio-emulsifiers & Hisatsuka et al., 1999 \\
\hline 6 & Whole cell & Cyanobacteria & Bio-flocculent & Levy, et al. [136] \\
\hline 7 & Surfactin/Iturin & B. subtilis, & Antimicrobial & Arguella et al., 2009 \\
\hline 8 & Subtilisin & B. subtilis & Antimicrobial properties & Sutyak, et al. [152] \\
\hline 9 & Aminoacids lipids & Bacillus sp & Antimicrobial properties & Cotter, et al. [117] \\
\hline 10 & Lichenysin & & Enhance oil recovery & Yakimov et al., 2009 \\
\hline
\end{tabular}

Manipulation of the plant microbiome has great potential in reducing the incidence of pests and diseases [37,38], promoting plant growth and plant fitness, and increasing productivity $[39,40]$. Single strains or mixed inoculum treatments induced resistance to multiple plant diseases [41]. In recent years, several microbial biofertilizers and inoculants were formulated, produced, marketed, and successfully used by farmers worldwide. Many processes in the rhizosphere lead to interactions been roots, microbes, water, and nutrients. For example, plant roots and microbes compete for nitrogen, and most likely other nutrients. The rhizosphere has been defined in terms of the effects of roots on soil microorganisms, the depletion of water [120], changes in $\mathrm{pH}$ [43], adhering soil [44], Hiltner [45] defined the rhizosphere as the soil influenced by roots. The rhizosphere is not a static place, but rather a dynamic system of processes and increasing the spatiotemporal resolution of rhizosphere measurements will lead to new insights and allows it to be considered as an extended phenotype [46], or an external manifestation of a plant's genetics.

\section{Rationale and Significance}

The cultivation of the resistance of Cassava Mosaic Disease (CMD) in response to chemical and biofertilizer using recommended application to study the crop yield and crops components was the object of the research. Planting one stake of cassava per hill or stand using $1 \mathrm{~m} \times 1 \mathrm{~m}$ spacing, by the National Root Crops Research Institute
(NRCRI) Umudike, Nigeria, was a major breakthrough in cassavabased farming system practices results to the production of larger roots, high yield per stand and makes other farm operations such as weeding and fertilizer application easy. The reasons advanced for the low adoption was low cassava population, low yield per unit area and weed growth in farms. Therefore, farmers are demanding for an increase in the number of cassavas to be planted per hill or with little or no chemical pesticides applied during cultivation. Cassava yields are compromised by pests such as whiteflies, mites, and weevils, which cause significant crop losses through the spread of viral disease and direct damage to plants which can reduce yields by up to $40 \%$ [47]. Studies shows the enhanced by the production of bioactive substances having similar effects as that of growth regulators besides nitrogen fixation through biofertilizer leading to greater dry matter production was reported by Ramanandam et al. [48]. The higher dry matter production is attributed to the cumulative effect of progressive increase in the growth attributes, viz., plant height, stem girth and number of leaves per plant [49]. Cassava is generally weeded by hand (hoe) 2-3 times during the first 3-4 months, but herbicides across the globe, Figure 3. The excitation (biofertilizer application) to the cassava cultivation soil system is functional characteristics of the impacts on rhizosphere considered for diagnostic tests of 'Biofertilizer rhizosphere holistic soil function'. With the narratives in Figure 2.

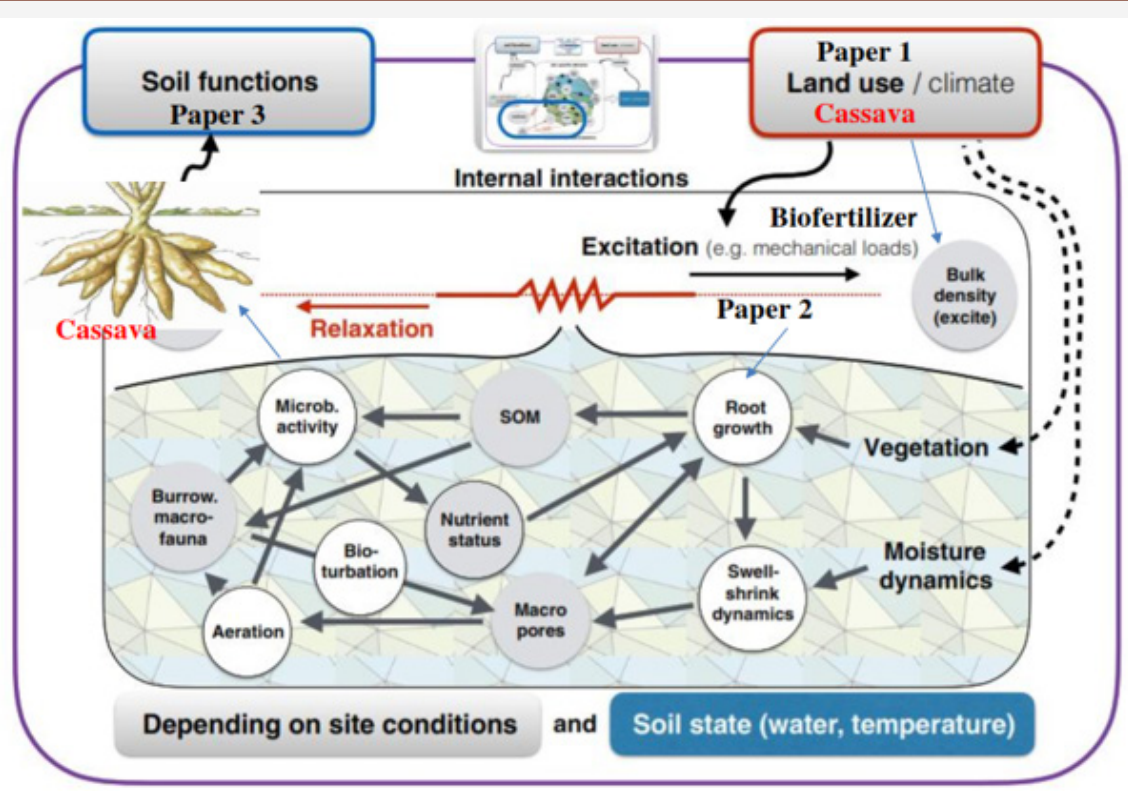

Figure 2: The excitation (biofertilizer application) to the cassava cultivation soil system is functional characteristics of the impacts on rhizosphere considered for diagnostic tests of 'Biofertilizer rhizosphere holistic soil function'. Where indicated by grey (Paper 1) circles while the connecting processes are in white (Paper 2) and Paper 3 (sustainable soil management).

Source: Adapted from Vogel, Hans-Jörg et al. [124]. 


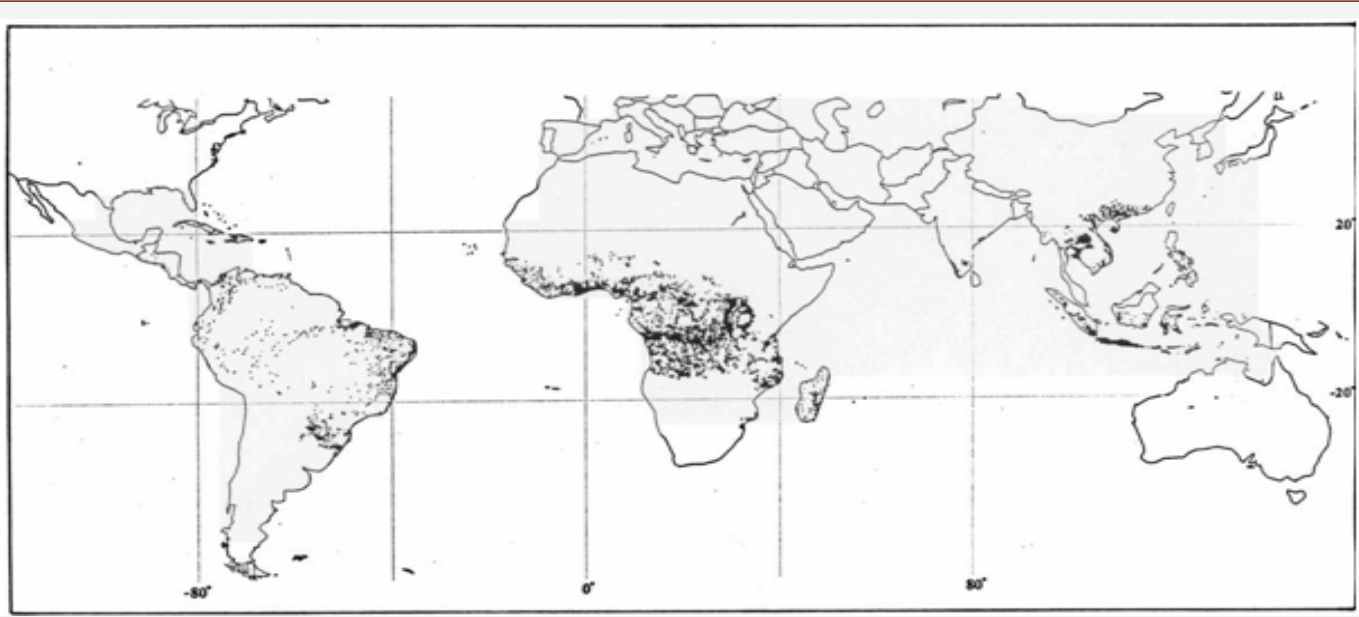

Figure 3: Distribution of cassava in the world. Each dot represents 1,000 ha. Adapted from Henry \& Gottret [4].

Optimizing cocktails of microorganisms inoculated in the biofertilizer production will produce microbial enzymes and metabolites, which mimic the multiplicity of bio-control mechanisms, set-up by microorganisms [50]. This category includes microbial secondary metabolites and hydrolytic enzymes as glucanases, proteases, lipases, and chitinases. These molecules can be used alone or, better, in combination; they can also be exploited in addition to chemical pesticides with the scope to favor their action, thus reducing the introduction and impact of synthetic pesticides on ecosystems. Yadav et al. [51] obtained consistently higher crop yield with NPK fertilizer mixed with organic manure over NPK inorganic fertilizer alone, Ano and Emehute [52] also obtained higher ginger rhizome yield with organic manure mixed with inorganic fertilizer over inorganic fertilizer alone. Complementary use of organic manure and inorganic fertilizer improves the soil resource base. The effect of biofertilizer on cassava microbiome and phytobiome is unknown or under investigation today. This research article series reports results application of accelerated OBD-Biofertilizer applied alone and in combination with inorganic fertilizer NPK (15:15:15).

The objectives of this paper are "biofertilizer rhizosphere diagnostic tests" to directly evaluate the dynamics of soil in response to targeted forcing (application of bio-fertilizer) in cassava cultivation in the tropic (eastern Nigeria). The observable dynamics provide information on the internal pattern of interacting processes of cassava-microbes interaction as an integral function of the impact of soil management and affirmed by Kibblewhite et al. [28] criticize the "reductionist" approach of using simple indicators describing some fixed state of the soil. In recent years, several microbial biofertilizers and inoculants were formulated, produced, marketed, and successfully used by farmers worldwide. The relationship between rhizodeposition and plant nutrient status is highlighted by the rhizosphere priming effect where $\mathrm{N}$ mineralization is increased near roots due to microbial activity [53]. The mapping of microbes in soil has identified microbial hotspots in the rhizosphere [54].

Better understanding of interactions between roots and rhizosphere processes promise to lead to new knowledge and mechanistic insights of the 'functions of rhizosphere microorganisms on cassava crop cultivation and development:

Paper 1: (Biofertilizer impacts on cassava (manihot esculenta crantz) Rhizosphere: Crop yield and Growth components, Igbariam, Nigeria).

Paper 2: (Biofertilizer impacts on cassava (manihot esculenta crantz) rhizosphere: Soil health and Quality, Igbariam, Nigeria).

Paper 3: (Biofertilizer Impacts on Cassava (Manihot Esculenta Crantz) Rhizosphere: Sustainable soil management, Igbariam, Nigeria).

These papers construct was affirmed by similar work of Cheng et al., [55], where the strategy of one organism depended on the strategies of others, demonstrated that rhizosphere priming could develop as a mutualism between plants and microbes in some limited ecological conditions. Such a systemic approach $\sim$ (Figure 3 ), providing a clear perspective on how soil functions emerge from small-scale process interactions, is a prerequisite to actually understanding the basic controls and to developing science-based strategies towards sustainable soil management [56].

\section{Materials and Method}

\section{Anaerobic digestion}

During the anaerobic digestion process, organic compounds are broken down, firstly via lactogenic bacteria to methane precursors, largely volatile fatty acids (VFAs) and then to methane and other products via methanogenic bacteria. OBD-Biofertilizer composted using anaerobic bio-digester technology (https://www.youtube. com/watch?v=Hi_OpgVcFcg biofertilizer) from bio-waste in anaerobic digester inoculated with beneficial microbes that exhibit differing metabolic capabilities. Under anaerobic conditions, organic forms of nitrogen (N) are converted into Ammonium-N (NH-N), i.e. readily available nitrogen.

The readily available nitrogen (RAN) content of cattle slurry is typically $50 \%$ and pig slurry $60 \%$ of Total-N [57]. It might be anticipated that a measurable increase in the proportion of readily 
available $\mathrm{N}$ would occur in these materials, as a result of the digestion process. Propagation of beneficial microbes. The isolated microbe was propagated using enriching non-selective medium (CPMA). The strains of each group were incubated separately for 7 days at $25{ }^{\circ} \mathrm{C}$ and then in mixture for 72 hours at $37{ }^{\circ} \mathrm{C}$ under agitation at $75 \mathrm{rpm}$. The bacterial isolates were then subjected to a series Gram staining and colony count [58]. The comparison was made against the database containing identification patterns for Gram positive and Gram-negative bacteria species.

\section{Bio-waste Recycling to Biofertilizer}

Agriculture bio-waste materials composted by anaerobic digester (AD) and inoculated with broad spectrum inoculants OTAI $\mathrm{AG}^{\circledR}$ (Table 2) and Oso Bio-Degrader (OBD-Plus ${ }^{\circledR}$ ) called microbial inoculants. Inoculated beneficial microbe's direct analysis of metabolites in situ has been achieved for antibiotic lipopeptides from several Bacillus subtilis and for pyrrolnitrin 2,4-diacetylphloroglucinol and phenazine-1-carboxylic acid from Pseudomonas fluorescens strains. During the anaerobic digestion process (Figure 4, Plates 1\&2) available for the biofertilizer production, Abeokuta, Nigeria.

YOU Tube https://www.youtube.com/watch?v=pG20DAx3ICY. OTAI $\mathrm{AG}^{\circledR}$ is PGPR (Table 2) and beneficial microbial inoculate an easy-to-use applied to the biowaste carrier material (composted) biofertilizer production with industrial standardized process of production and similar to the report by Schmidt [31]. Biofertilizers price is not the same as composts and have been tested as growth media for PGPR [31]. PGPR and/or arbuscular mycorrhizal fungi (AMF) [59] combine inoculation often resulted in increased growth and yield, compared to single inoculation through improved nutrient uptake [60] and resultant interaction of bacteria and AM fungi have beneficial functions related to nutrient uptake, particularly when PGPR [61] and N2-fixing bacteria are involved. Survival of the PGPR is important both during the storage period of the bioproduct and after being introduced into the soil for solid carriers, powder or granules. Standard sizes of the powder material may vary from 75 $\mu \mathrm{m}$ to $0.25 \mathrm{~mm}$ [62] and application methods depend on the kind of crop concerned can be inoculated by broadcasting the inoculum over the soil surface, alone or together with seeds, or by in-furrow application, seed dressing, or coating; tree crops can be initially inoculated by root dipping or seedling inoculation [63].

Chemical analyses: Total Nitrogen Kjeldahl procedure [64]; Available P Olsen's method [65]; Available K by Flame photometric method [66]; pH [67]; Electrical Conductivity by Walkley Black method [68]; Micronutrients (Zinc, Iron, Copper, Manganese) ppm Atomic absorption Spectrophotometric method using DTPA (Diethyl Triamine Penta Acetic Acid) by Lindsay and Norvell [69].

\section{Results and Discussion}

\section{Bioferilizer physico-chemical properties}

Bio-fertilizers contained $3.5 \%-4 \%$ nitrogen, $2 \%-2.5 \%$ phosphorus and $1.5 \%$ potassium. The nutrient content of the OBDBiofertilizer indicated the followings:
- $\quad$ Macroonutrients: $\mathrm{pH}$ in water (5.8); \%N (0.95); \%P (3.1); \% Ca (13.05); \%Mg (0.79) \%K (0.35); ppm Na (40.74); ppm Mn (456.78); ppm Fe (460.01); ppm Cu (17.47); ppm Zn (95.5); \%Carbon (35.68) and

- $\quad \mathrm{C} / \mathrm{N}$ ratio (35.56).

- $\quad$ Micronutrients: Molybdenum (Mo) 20 ppm; Boron (B) 30ppm; Copper (Cu) 17.47ppm; Manganese (Mn) 456.78 ppm; Zinc (Zn) 95.5 ppm; Iron (Fe) 460.01 ppm; Sodium (Na) 40.74ppm.

- Essential Nutrients: Humic acid 2.1. Beneficial microorganisms presents are in the OBD-Biofertilizer: Azotobacter spp, Clostridium spp, Bacillus spp, Esherichia, Rhizobium spp. Fe (iii) reducing Bacteria (Shewanella putrefaciens), Phosphate Solubilizing Fungi (Actnomycetes), Potassium Solubilizing Bacteria (Bacillus mucilaginous), Phosphate Solubilizing Bacteria (Rhizobium, Agrobacterium), Sulphur Oxidising Bacteria (Thiobacillus thioxidans).

- Materials: Shea cake and Poultry waste (SPW), Swine waste (SW), Wood ash (WA)

- $\quad$ Ratios: SPW 12: SW 12.5: WA 1.

- $\quad$ Percentages: PW 47.06; SW 49.02; WA 3.92

- $\quad$ Microbial Inoculants: OBD-Plus ${ }^{\circledR}$ and OTAI $\mathrm{AG}^{\circledR}$

The trial was conducted at the National Root Crops Research Institute's, substation in Igbariam in 2012/2013 cropping seasons, Anambra state, Nigeria. The soil was an Ultisol and had a $\mathrm{pH}$ in water of 5.0, 2.06\% organic matter, $0.14 \%$ total nitrogen, $5.8 \mathrm{mg} / \mathrm{kg}$ Bray $2 \mathrm{P}$, exchangeable calcium, $\mathrm{Mg}$ and $\mathrm{K}$ of $4.60 \mathrm{cmol} / \mathrm{kg}, 2.50 \mathrm{cmol} /$ $\mathrm{kg}$ and $0.12 \mathrm{cmol} / \mathrm{kg}$ respectively. The field was slashed ploughed, harrowed and ridged, thereafter plots each measuring $5 \mathrm{~m} \times 5 \mathrm{~m}$ were marked out. Cassava stakes each measuring about $25 \mathrm{~cm}$ were then planted at $1 \mathrm{~m} \times 1 \mathrm{~m}$ spacing on top of the ridges on $16^{\text {th }}$ November 2012. Cassava Mosaic Disease (CMD) resistant varieties used was from the International Institute of Tropical Agriculture's (IITA) fields. The treatment was arranged in a randomized complete block design replicated three times. The treatments were as follow:

- $\quad 300 \mathrm{~kg} / \mathrm{ha}$ NPK 15:15:15 + 1.0 t/ha

OBD- Biofertilizer

- $\quad 300 \mathrm{~kg} / \mathrm{ha}$ NPK 15:15:15 + 2.0 t/ha

OBD-Biofertilizer

- $\quad 300 \mathrm{~kg} / \mathrm{ha}$ NPK 15:15:15 + 3.0 t/ha

OBD-Biofertilizer

- $\quad 300 \mathrm{~kg} / \mathrm{ha}$ NPK 15:15:15 + $4.0 \mathrm{t} / \mathrm{ha}$

OBD-Biofertilizer

- 2.0 t/ha OBD-Biofertilizer

- $\quad 600 \mathrm{~kg} / \mathrm{ha}$ NPK $(15: 15: 15)$ 
- $\quad$ Control (no application).

- $\quad$ The treatments were applied on $9^{\text {th }}$ May 2013. Harvesting of cassava was carried out in November 2013 and the fresh root yield was measured. The data obtained was subjected to analysis of variance. Significant treatment means were separated using Fischer's least significant difference (F-LSD) at 5\% probability and see Plates 1 and 2 below.

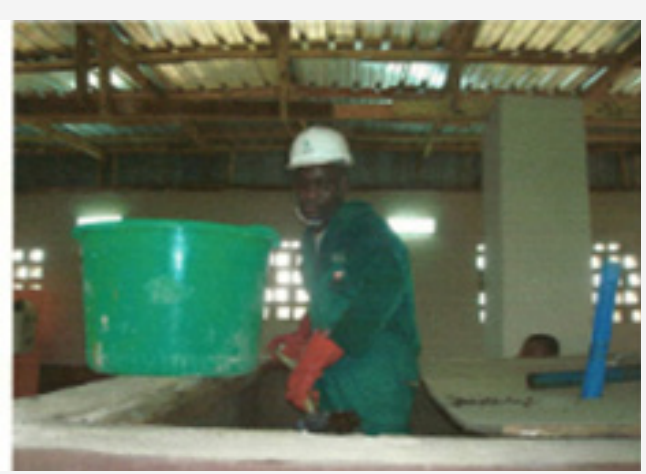

Plate 1: Anaerobic digester Old design do not produce, 2009, UNDP Project.

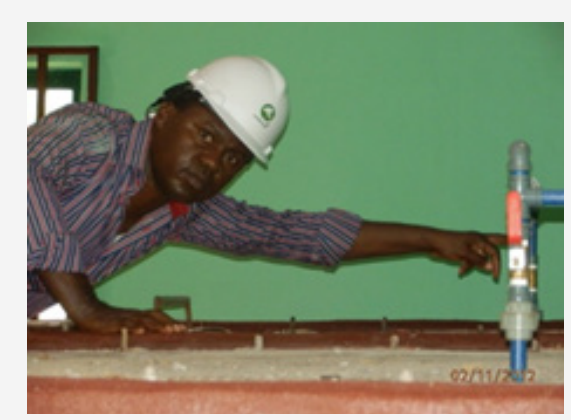

Plate 2: Anaerobic digester New design to capture the biogas produced, NESREA Port Harcourt, 2012.

- The effect of OBD-Biofertilizer applied alone and in combination with inorganic fertilizer on cassava root yield is shown in Table 3. Application of either inorganic fertilizer, OBD-Biofertilizer alone, OBD-Biofertilizer in combination with inorganic fertilizer gave significantly higher cassava root yield $(\mathrm{P}<0.05)$ than the control (no application). Inorganic fertilizer applied at the recommended rate of $600 \mathrm{~kg}$ NPK (15:15:15) / ha also gave higher cassava root yield than OBD-Biofertilizer applied either alone or in combination with inorganic fertilizer.

Table 3: Effect of OBD -Biofertilizer applied alone and in combination with inorganic fertilizer on cassava root yield.

\begin{tabular}{|c|c|c|}
\hline S/N & Treatments & $\begin{array}{c}\text { Cassava Root } \\
\text { Yield (t/ha) }\end{array}$ \\
\hline 1 & $\begin{array}{c}300 \mathrm{~kg} / \mathrm{ha} \text { NPK 15:15:15 + 1.0 t/ha } \\
\text { OBD-Biofertilizer }\end{array}$ & 20.5 \\
\hline 2 & $\begin{array}{c}300 \mathrm{~kg} / \mathrm{ha} \text { NPK 15:15:15 + 2.0 t/ha } \\
\text { OBD-Biofertilizer }\end{array}$ & 22 \\
\hline 3 & $\begin{array}{c}300 \mathrm{~kg} / \mathrm{ha} \mathrm{NPK} \mathrm{15:15:15+3.0} \mathrm{t/ha} \\
\text { OBD-Biofertilizer }\end{array}$ & 30 \\
\hline 4 & $300 \mathrm{~kg} / \mathrm{ha}$ NPK 15:15:15 + 4.0t/ha \\
OBD-Biofertilizer & 31.2 \\
\hline 5 & 5.0 t/ha OBD-Biofertilizer & 16 \\
\hline 6 & $600 \mathrm{~kg} / \mathrm{ha}$ NPK (15:15:15) & 35.6 \\
\hline 7 & Control (no application) & 12 \\
\hline & F-LSD (0.05) & 3 \\
\hline
\end{tabular}

OBD-Biofertilizer applied at the rate of $4 \mathrm{t} /$ ha mixed with 300 $\mathrm{kg}$ NPK (15:15:15) /ha gave the highest cassava root yield of 31.2 t/ha which was however not significantly higher than $30.0 \mathrm{t} / \mathrm{ha}$ obtained with OBD-Biofertilizer applied at the rate of $3 \mathrm{t} /$ ha mixed with $300 \mathrm{~kg}$ NPK (15:15:15)/ ha. Complementary use of OBDBiofertilizer and inorganic fertilizer is therefore more beneficial than OBD-Biofertilizer alone in cassava production. This result is in agreement with Ano \& Ikwelle [70] and Mokwunye, [71]. Soils of the experimental site and indeed most Nigerian soils are highly weathered and have low activity clays [72] and therefore require application of soil amendment for high crop yield to be obtained. This explains why inorganic fertilizer NPK 15:15:15 applied at the recommended rate of $600 \mathrm{~kg} / \mathrm{ha}$ or inorganic fertilizer applied at $300 \mathrm{~kg} /$ ha mixed with OBD-Biofertilizer gave significantly higher yield than the control, Figure 4.

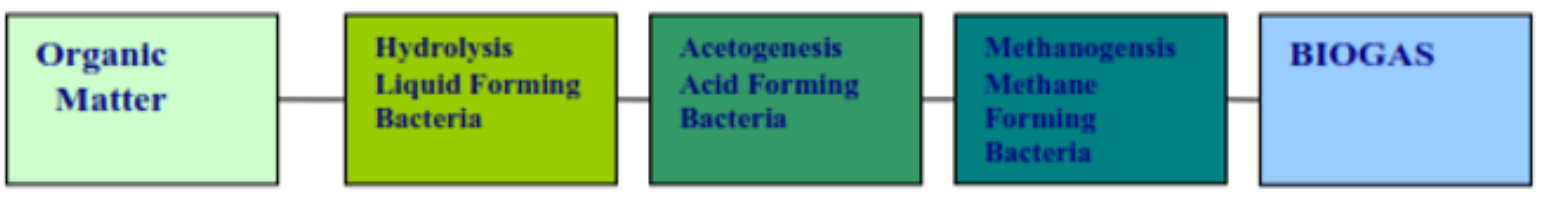

Figure 4: Anaerobic digestion is a multi-stage process.

\section{Agronomic Practices}

\section{Enhancing the adoption of soil conservation practices}

Cassava is well adapted to low fertility soils that predominate in large areas of the tropics. It is frequently cultivated on the highly weathered and leached Oxisols, Ultisols and Alfisols, with smaller areas found on Inceptisols (particularly in India) and Entisols. Cassava is extremely tolerant of low soil $\mathrm{pH}$ and high levels of aluminum saturation that often accompany them. It can be found producing moderate yields where many crops simply fail due to the low pH and high levels of aluminum [3]. The highest yields were obtained using the full land preparation methods, including twice plowing and disking followed by contour ridging? To reduce erosion peanut intercrop, with cassava planted on contour ridges, with or without fertilizer application and planting on contour ridges resulted in a decrease in soil loss of almost 40\% [73]. At planting time, there should be enough soil moisture to get at least $80-90 \%$ germination, while soils should not be too wet to prevent adequate aeration and root formation [74]. 


\section{Growth, Yield and Root Quality}

\section{Biofertilizer facilitate the below-ground}

Table 4: Effect of OBD -Biofertilizer applied alone and in combination with inorganic fertilizer on cassava root yield.

\begin{tabular}{|c|c|c|}
\hline $\mathbf{S} / \mathbf{N}$ & Treatments & $\begin{array}{l}\text { Cassava Root } \\
\text { Yield (t/ha) }\end{array}$ \\
\hline 1 & $\begin{array}{c}300 \mathrm{~kg} / \mathrm{ha} \mathrm{NPK} \mathrm{15:15:15} \mathrm{+} 1.0 \mathrm{t} / \mathrm{ha} \\
\text { OBD-Biofertilizer }\end{array}$ & 20.5 \\
\hline 2 & $\begin{array}{l}300 \mathrm{~kg} / \mathrm{ha} \text { NPK 15:15:15 + } 2.0 \mathrm{t} / \mathrm{ha} \\
\text { OBD-Biofertilizer }\end{array}$ & 22 \\
\hline 3 & $\begin{array}{c}300 \mathrm{~kg} / \mathrm{ha} \text { NPK 15:15:15 + } 3.0 \mathrm{t} / \mathrm{ha} \\
\text { OBD-Biofertilizer }\end{array}$ & 30 \\
\hline 4 & $\begin{array}{c}300 \mathrm{~kg} / \mathrm{ha} \text { NPK 15:15:15 + 4.0t/ha } \\
\text { OBD-Biofertilizer }\end{array}$ & 31.2 \\
\hline 5 & $5.0 \mathrm{t} / \mathrm{ha}$ OBD-Biofertilizer & 16 \\
\hline 6 & 600 kg/ha NPK (15:15:15) & 35.6 \\
\hline \multirow[t]{2}{*}{7} & Control (no application) & 12 \\
\hline & F-LSD (0.05) & 3 \\
\hline
\end{tabular}

Biological activity of earthworms, bacteria and fungi, and supply a wide range of nutrients, including secondary and micronutrients (Table 4). Adoa [75] reported highest plant height with the application of poultry manure on Nkabom and IFAD cassava varieties. Adjei-Nsiah \& Issaka [76] observed that average fresh tuber yield increase from $13.7 \mathrm{t} /$ ha without amendment to $23.7 \mathrm{t} /$ ha with application of $4 \mathrm{t} / \mathrm{h}$ a poultry manure and compared with Table 4 where biofertilizer application at 5t/ha yield $16 \mathrm{t} /$ ha and control yield $12 \mathrm{t} /$ ha (Figure 5 ) due to the impacts of the beneficial microorganisms. Organic fertilizer promotes the growth of stems and leaves of cassava, increase the chlorophyll content and the photosynthesis of leaves and improve the physiological metabolism of cassava [77]. The period of maximum rate of dry matter partitioning depends on genotype-by-environmental interaction [9].

Amanullah et al. [49] observed that the number of roots per plant was significantly influenced by organic fertilizer treatment steady availability of nutrients throughout the crop growth period favorable changes in soil, such as loose and friable soil conditions, enabling better root formation. An increase in the number of storage roots per plant in response to organic fertilizer application has been reported by Pellet \& El- Sharkawy [78]. Leo \& Kabambe [79], observed a significant increase in number of roots per plant, and tuber diameter having a positive correlation with fertilizer treatment. Manure application has resulted in higher root yields of cassava [80]. Manure application enhances the cooking quality (mealiness) of cassava [75]. Various observations have been made of a positive correlation between dry matter content and cooking quality of cassava [81].

The delicate balance between top growth and root growth is the key to understanding the growth and development of cassava [82]. The photosynthetic rate of plants obtained from mother plants that have not been fertilized is similar to that of fertilized mother plants. The status of the nutrient reserves is important for the establishment is important in determining final yield [83] and that confirmed the properties of the biofertilizer in root crops development. The number of thickened roots is determined early in the growth cycle, normally in the first three months [84]. The fibrous feeder roots of cassava were described as being rather sparse by Connor et al. [85], reaching a maximum level of $1 \mathrm{~km} / \mathrm{m}^{2}$ and depths of at least $2.6 \mathrm{~m}$.

\section{Biofertilizer and Inorganic Fertilizer}

Table 5: Comparative analysis of Treatments Materials for Cassava Cultivation.

\begin{tabular}{|c|c|c|c|c|c|}
\hline N/B & $\begin{array}{l}\text { Treatment } \\
\text { Materials }\end{array}$ & $\begin{array}{l}\text { Control } \\
\text { Yield/Ton }\end{array}$ & $\begin{array}{l}\text { Treatment/ } \\
\text { Yield /ton }\end{array}$ & Impacts on Crop Component & References \\
\hline \multirow{13}{*}{1} & \multirow{3}{*}{ Poultry manure } & \multirow{3}{*}{$13.7 \mathrm{t} / \mathrm{ha}$} & \multirow{3}{*}{$23.7 \mathrm{t} / \mathrm{ha}$} & $\begin{array}{l}\text { Cell elongation of plant tissues as a result of } \\
\text { steady release }\end{array}$ & Sharma \& Govil [147] \\
\hline & & & & and mineralization of nutrients & Christopher, et al., 2007; Adoa [75] \\
\hline & & & & Highest nutrient content & Susan, et al. [151] \\
\hline & \multicolumn{5}{|c|}{ IFAD cassava varieties. } \\
\hline & \multirow{9}{*}{$4 \mathrm{t} / \mathrm{ha}$} & \multirow{9}{*}{$13.7 \mathrm{t} / \mathrm{ha}$} & \multirow{9}{*}{$23.7 \mathrm{t} / \mathrm{ha}$} & $\begin{array}{l}\text { Increase the chlorophyll content in stem/leaves } \\
\text { and }\end{array}$ & Adjei-Nsiah \& Issaka [151] \\
\hline & & & & $\begin{array}{l}\text { the photosynthesis and physiological metabo- } \\
\text { lism }\end{array}$ & Luo, et al. [77] \\
\hline & & & & $\begin{array}{l}\text { Dry matter partitioning depends on geno- } \\
\text { type-by-environmental }\end{array}$ & Fregence, et al. [9]; Lebot, 2009 \\
\hline & & & & interaction & \\
\hline & & & & Higher root yields of cassava & $\begin{array}{l}\text { Wilson \& Dufour, 2002; Agbaje \& Akin- } \\
\text { losotu [80]; ssaka, et al. 2007; }\end{array}$ \\
\hline & & & & & Ojeniyi, et al. [87] \\
\hline & & & & Enhances the cooking quality (mealiness) & Adoa [75] \\
\hline & & & & $\begin{array}{l}\text { Positive correlation between dry matter content } \\
\text { and }\end{array}$ & Safo-Kantanka \& Asare [81] \\
\hline & & & & cooking quality & Safo-Kantanka \& Owusu Nipa [62] \\
\hline
\end{tabular}




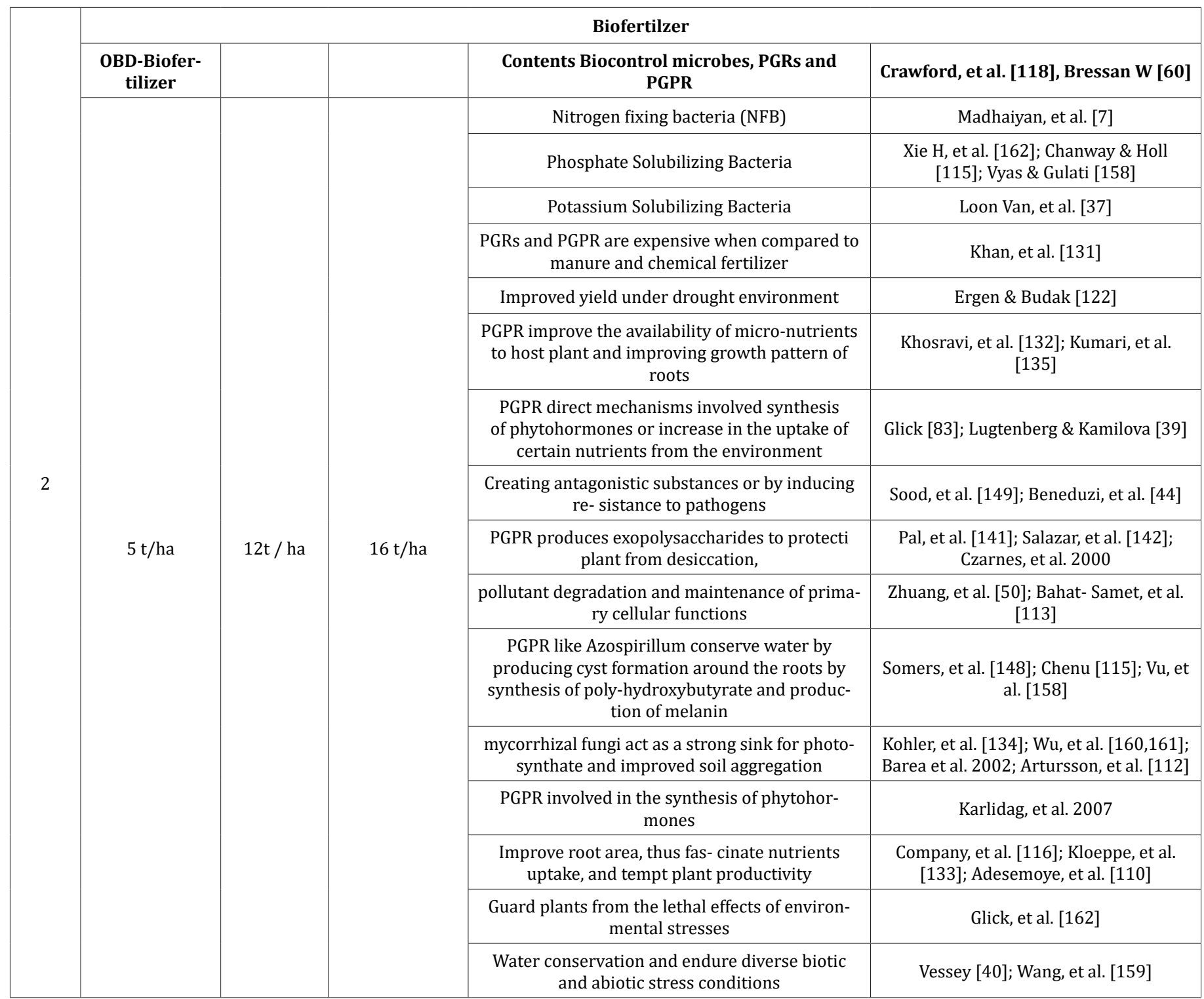

The use of mineral fertilizer in combination with poultry manure has shown an increase yield as much as $60 \mathrm{t} / \mathrm{h}$ a of cassava roots [68]. The fertilizers supplied the bulk of the macronutrients needed by the plants, while the organic sources provide secondary and micronutrients which are only needed in very small quantities and improve the soil's physical conditions $[86,87]$ as confirmed in the Table 5 and Figure 4 where treatments with $600 \mathrm{~kg} / \mathrm{ha}$ NPK 15:15:15 had a yield of $35.6 \mathrm{t} / \mathrm{h}$ a and $300 \mathrm{~kg} / \mathrm{ha}$ NPK 15:15:15 + 3 t/ha OBD-Biofertilizer had a yield of 30 t/ha using Fischer's least significant difference (F-LSD) at 5\% probability due to the impacts of microbial metabolic processes related to Plant nutrition in the biofertilizer .Nutrients contained in organic manures are released more slowly and are stored for a longer time in the soil, thereby ensuring a long residual effect [88]. A combined use will increase synchrony and reduce losses by converting inorganic $\mathrm{N}$ into organic forms [89]. The resultant impacts is integrated nutrient management programmed with increase cassava yield through improving soil productivity, higher fertilizer use efficiency, reduces the environmental problems that may arise from the use of sole inorganic fertilizers and improves the microbial properties of the soil and sustain maximum crop productivity and profitability [90]. Endophytes are also of special interest for their high number of microbial niches and environments they may inhabit and provide therefore a high potential as a less exploited resource. A lack of either $\mathrm{N}$ or $\mathrm{P}$ application to mother plants did not significantly affect the rate of sprouting, whereas a lack of $\mathrm{K}$ application reduced it significantly [41].

\section{Impacts of photosynthesis}

The $\mathrm{C}_{4}$ plants tend not to light saturate, have low photorespiration, high photosynthetic rates on a per unit leaf area basis and hence are also nitrogen and water use efficient. Cassava has normally been considered to be a typical $C_{3}$ plant $[91,92]$. The photosynthetic rates reported by El Sharkawy [93] for cassava in field grown plants $\left(40 \mu \mathrm{mol} \mathrm{CO} \mathrm{CO}_{2} / \mathrm{m}^{2} / \mathrm{s}\right)$ are high for a $\mathrm{C}_{3}$ plant. Furthermore, wild species of Manihot have photosynthetic rates as high as $50 \mu \mathrm{mol} \mathrm{CO} / 2 \mathrm{~m}^{2} / \mathrm{s}$ [93]. Work at CIAT suggested that cassava might be $\mathrm{a} \mathrm{C}_{3}-\mathrm{C}_{4}$ intermediate [94]. Connor \& Palta [95] found that cassava stomata closed in well-watered and stressed plants in the field at midday. Cassava stomata are extremely sensitive to the Vapor Pressure Deficit (VPD) between the leaf and the air [39]. A 
whole series of trials have shown a relation between photosynthetic rate of individual leaves and the root yield of cassava under stressed and unstressed conditions. El Sharkawy et al. [96] found that photosynthetic rate measured in preliminary yield trials was correlated with root yield in subsequent independent yield trials.

Increased yield associated with increased photosynthetic rate, as expected, increases the nitrogen use efficiency [96], and also, presumably, water use efficiency. Furthermore, recently it has been shown that activity of PEP carboxylase, an enzyme associated with C4 photosynthesis, is correlated with photosynthetic rate and yield. Thus, it might be easier to screen parent materials for crosses for their PEP carboxylase activity in breeding programs. The dry matter content of cassava roots ranges from about $25 \%$ to up to $40 \%$. Hence, it is more cost effective to produce high dry matter products [97]. The dry matter content of cassava roots is a varietal characteristic. The drop in dry matter content is probably due to mobilization of starch reserves in the roots to support the flush of new leaves [98]. Consequently, it is not uncommon for stressed plants of vigorous varieties to produce more roots than unstressed plants [95]. Cassava is capable of exploiting the available water to a depth of $2 \mathrm{~m}$ [99]. In a fairly typical soil, the cassava plant can extract the equivalent of $160 \mathrm{~mm}$ of soil water during a drought period [93]. Rather than growing continuously and ending up with low levels of nutrients in plant tissue, the cassava plant tends to reduce its growth according to the available nutrients (Plates 3 \& 4). This is particularly true in the case of nitrogen [100] but appears to be less so in the case of phosphorous [101] and potassium. Nevertheless, on extremely low phosphorous soils, well managed to maintain effective strains of mycorrhiza, cassava performs very well [102]. Since nutrient removal is mainly a function of yield, it is more practical to calculate nutrient removal per ton of fresh roots harvested. Howeler [73] at harvest reported only the crop removes mainly $\mathrm{K}$, less $\mathrm{N}$ and very little $\mathrm{P}$.

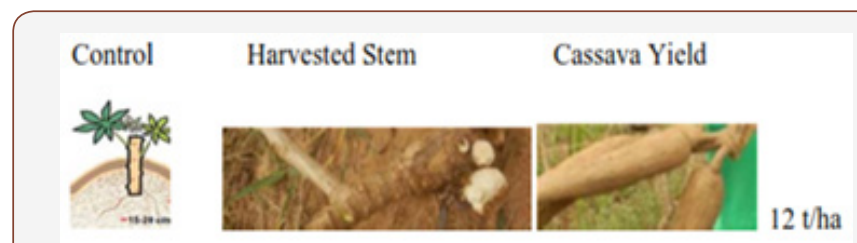

Plate 3: Control field Casaava experiment.

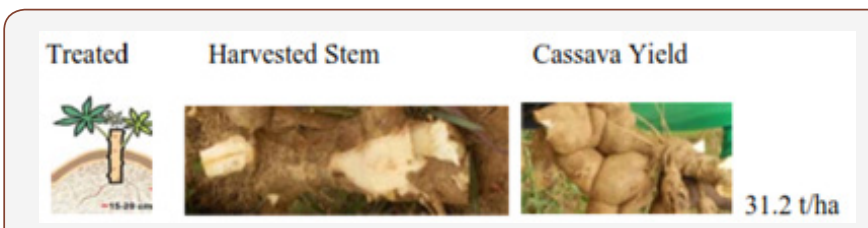

Plate 4: Treated field cassava experiment using Biofertilizer.

\section{Cassava Products and Markets}

Cassava roots and leaves (or young plant tops) have multiple end-uses, including for direct human consumption of fresh roots and leaves (after boiling), on-farm animal feeding, commercial production of animal feed, and production of starch or starch derivatives, Figure 5. Most of the chips and pellets are used for production of alcohol and animal feed, respectively. Besides dry chips, China also imported nearly 1.2 million tons of cassava starch, much of which is being converted to modified starch within China. China itself was producing about 4.5 million tons of fresh roots in 2009 [103], while importing the equivalent of 18.7 million tons of fresh roots. In China, cassava starch production was about 900,000 tons in 2007, while an additional 500,000 tons of cassava starch were imported [104].

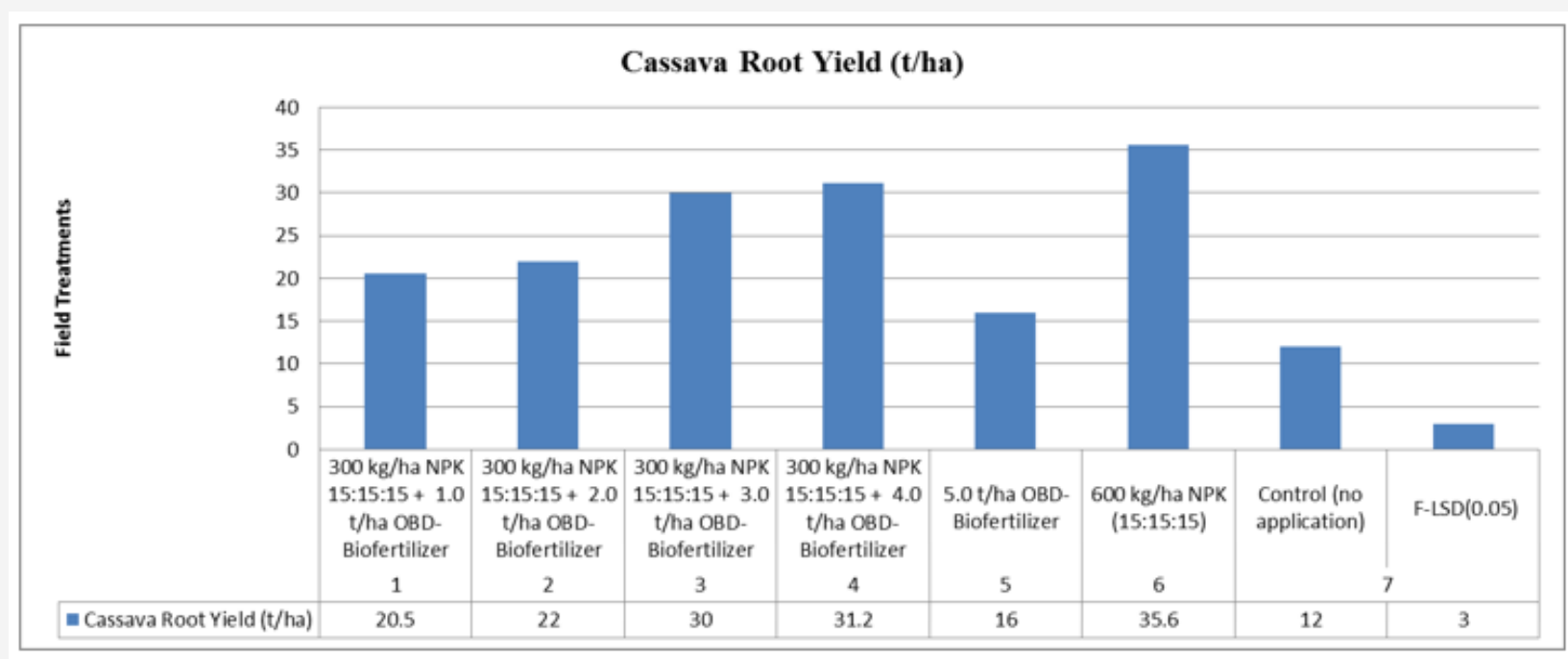

Figure 5: Field application yield of application of biofertilizer and complementary use of NPK (15:15:15).

\section{Starch-based sweeteners and Hydrogenated sweeteners}

Cassava starch can be used for the production of many types of sweeteners after hydrolyzation by either acids or enzymes, or both. These sweeteners include maltose, glucose syrup, glucose and fructose, which can be further processed into various oligosaccharides [105]. Hydrogenated sweeteners are produced by treating starch with hydrogen gas in high-pressure tanks, using a special catalyst and ion-exchange resins. These include sorbitol, 
mannitol and maltol. Sorbitol is used mainly for the production of vitamin C and as a moisture conditioner in toothpastes [106].

\section{Organic acids and Monosodium glutamate (MSG) and lysine}

Organic acids made from cassava starch include citric acid, acetic acid, lactic acid and it aconic acid, which are used in the food industry as well as for the production of plastics, synthetic resins, rubber products etc. Lactic acid is produced by the fermentation of starch with Lactobacillus amylovorus [107]. MSG is a well-known flavor-enhancing agent used in many Asian kitchens. It is made through the microbial fermentation of starch or sugar (molasses) in the presence of ammonium salts. Lysine is an important amino acid used as a supplement in animal feed, especially for pigs.

\section{Degradable plastics and Ethanol}

Various types of starches are being used for the production of bio- or photo-degradable plastics, either by mixing starch or modified starch with polyvinyl hydrocarbons, or by polymerization of starch, which is then blended with various other polymers [108]. The use of cassava starch for these processes still requires much research. Cassava as the feedstock for the production of ethanol; this includes drinking alcohol, industrial alcohol and fuel-alcohol. The latter is also called "dehydrated" or "anhydrous" ethanol and must be $99.5 \%$ pure ethanol.

\section{Conclusion}

Cassava production has continued to expand throughout the lowland tropics, mainly on the less-fertile, poor-quality agricultural lands. The quality of farm-inputs affects the quality of cassava yield and soil health as confirmed in the report of Yomeni et al. [109]. Poor quality planting material is often associated with marginal growth and productivity of cassava. Microbial inoculants have paramount significance in integrated nutrient management systems to sustain agricultural productivity and healthy environment [110]. Application of $300 \mathrm{~kg} /$ ha NPK 15:15:15 + 3t/ha OBD-Biofertilizer gave high cassava root yield and is recommended for cassava production on soils having similar characteristics as the soil of the field experimental site (Table 5). Environmental stresses are becoming a major problem and productivity is declining at an unprecedented rate. Biofertilizers can help solve the problem of feeding an increasing global population at a time when agriculture is facing various environmental stresses [111-128]. It is important to realize the useful aspects of biofertilizers and implement its application to modern agricultural practices (Table 6). The use of farmer participatory research (FPR) and extension (FPE) methodologies, in which farmers become directly involved in the testing, selection and dissemination of new technologies will enhance crop development [129-142].

Table 6: Combine Organic/Chemical Fertilizers Application to Cassava Crop.

\begin{tabular}{|c|c|c|c|c|c|}
\hline N/B & Treatment Materials & $\begin{array}{l}\text { Control } \\
\text { yield/Ton }\end{array}$ & $\begin{array}{l}\text { Treatment/ } \\
\text { Yield /ton }\end{array}$ & Impacts on Crop Component & References \\
\hline \multirow{5}{*}{1} & \multirow{5}{*}{ Mineral fertilizer/Poultry manure } & & \multirow{5}{*}{$60 \mathrm{t} / \mathrm{ha}$} & $\begin{array}{l}\text { Chemical fertilizers supplied the bulk } \\
\text { of the macronutrients }\end{array}$ & CSIR- AGRA [68] \\
\hline & & & & needed by the plants & FAO [86] \\
\hline & & & & $\begin{array}{l}\text { Organic sources provide secondary } \\
\text { and micronutrients }\end{array}$ & \\
\hline & & & & $\begin{array}{l}\text { Good soil fertility management } \\
\text { strategy. }\end{array}$ & $\begin{array}{l}\text { Ojeniyi, et al. } \\
\quad 2012\end{array}$ \\
\hline & & & & Higher fertilizer use efficiency. & $\begin{array}{l}\text { Santhi \& Selvaku- } \\
\text { mari } 2000\end{array}$ \\
\hline \multirow{8}{*}{2} & \multicolumn{5}{|c|}{ Biofertilizer } \\
\hline & OBD-Biofertilizer & & & $\begin{array}{l}\text { Integrated nutrient management } \\
\text { programme }\end{array}$ & $\begin{array}{l}\text { Ayoola \& Ma- } \\
\text { kinde (2007) }\end{array}$ \\
\hline & $\begin{array}{c}\text { Urea/NPK 15:15:15/OBD-Biofer- } \\
\text { tilizer Formulation }\end{array}$ & & & $\begin{array}{l}\text { Slow release fertilizer ensuring a long } \\
\text { residual effect }\end{array}$ & Tisdale, et al. [88] \\
\hline & $\begin{array}{c}300 \text { kg/ha NPK 15:15:15 + } 1.0 \mathrm{t} / \\
\text { ha OBD-Biofertilizer }\end{array}$ & $12 \mathrm{t} / \mathrm{ha}$ & $20.5 \mathrm{t} / \mathrm{ha}$ & $\begin{array}{l}\text { Reduce losses by converting inorgan- } \\
\text { ic N into organic forms }\end{array}$ & Kramer, et al. [89] \\
\hline & $\begin{array}{c}300 \text { kg/ha NPK 15:15:15 + } 2.0 \mathrm{t} / \\
\text { ha OBD-Biofertilizer }\end{array}$ & & $22 \mathrm{t} / \mathrm{ha}$ & $\begin{array}{l}\text { Improves the microbial properties of } \\
\text { the soil }\end{array}$ & Belay et al., 2001 \\
\hline & $\begin{array}{c}300 \text { kg/ha NPK 15:15:15 + } 3.0 \text { t/ } \\
\text { ha OBD- Biofertilizer }\end{array}$ & & 30 t/ha & $\begin{array}{l}\text { Sustain maximum crop productivity } \\
\text { and profitability }\end{array}$ & Ayeni [90] \\
\hline & $\begin{array}{c}300 \text { kg/ha NPK 15:15:15 + } 4.0 \text { t/ } \\
\text { ha OBD- Biofertilizer }\end{array}$ & & $31.2 \mathrm{t} / \mathrm{ha}$ & $\begin{array}{l}\text { Minimizing environmental impact } \\
\text { from nutrient use }\end{array}$ & \\
\hline & 600 kg/ha NPK (15:15:15) & & $35.6 \mathrm{t} / \mathrm{ha}$ & & \\
\hline
\end{tabular}

In Figure 2, excitation (biofertilizer application) to the cassava cultivation soil system is functional characteristics of the impacts on rhizosphere considered for diagnostic tests of 'Biofertilizer rhizosphere holistic soil function'. Where indicated by grey (Paper
1) circles while the connecting processes are in white (Paper 2) and Paper 3 (sustainable soil management) [143-164].

\section{Acknowledgement}

None. 


\section{Conflict of Interest}

No conflict of interest.

\section{References}

1. Cock JH, RH Howeler (1979) The ability of cassava to grow on poor soils In: GA Jung (Ed.). Crop Tolerance to Sub-Optimal Land Conditions. ASA Special Publication, Madison, WI, USA 32: 145-154.

2. Kawano K, JH Cock (2005) Breeding cassava for the underprivileged: Institutional, socio-economic and biological factors for success. J Crop Improv 14(1-2): 197-219.

3. Cock JH (1985) Cassava: New Potential for a Neglected Crop. Westview, Boulder, USA, $191 \mathrm{p}$.

4. Henry G, V Gottret (1996) Global Cassava Trends. Reassessing the Crop's Future. CIAT Working Document No. 157, CIAT, Cali Colombia, 45 p.

5. Howeler RH (1991) Long term effects of cassava cultivation on productivity. Field Crop Research 26(1): 1-18.

6. Onwueme IC, Charles WB (Kana) Tropical root and tuber crops: production, perspective and future prospects. Food and Agriculture Organization of the United Nations.

7. Madhaiyan M, Poonguzhali S, Kang BG, Lee YJ, Chung JB, et al. (2010) Effect of co-inoculation of methylotrophic Methylobacterium oryzae with Azospirillum brasilense and Burkholderia pyrrocinia on the growth and nutrient uptake of tomato, red pepper and rice. Plant Soil 328: 71-82.

8. Weite Z, Xiong L, Kaimian L, Tie H (1998) Fermer's participatory research in cassava soil management varietal dissemination in China. In Howeler RH (Ed) Cassava Breeding Agronomy and Farmer Participatory Research in Asia, Proceeding $5^{\text {th }}$ Regional Workshop, Dan Zhou, China, pp. 389-411.

9. Fregence MA, Vargas J, Ikea J, Angel P, Tohme J, et al. (1994) Variability of chloroplast DNA and nuclear ribosomal DNA in cassava (Manihot Esculenta Crantz) and its wild relatives. Theoretical and Applied Genetics 89(6): 719-727.

10. Singh JS, Pandey VC, Singh DP (2011) Efficient soil microorganisms: a new dimension for sustainable agriculture and environmental development. Agric Ecosyst Environ 140(3-4): 339-353.

11. Fregene M, A Bernal, M Duque, A Dixon, J Tohme (2000) AFLP analysis of African cassava (Manihot esculenta Crantz) germplasm resistant to the cassava mosaic disease (CMD). Theoretical and Applied Genetics 100(5): 678-685

12. Fregene M, F Angel, R Gomez, F Rodríguez, P Chavarriaga, et al. (1997) A molecular genetic map of cassava (Manihot esculenta Crantz) Theoretical and Applied Genetics 95(3): 431-441.

13. Blair MW, MA Fregene, SE Beebe, H Ceballos (2007) Marker assisted selection in common beans and cassava. In: EP Guimaraes, J Ruane, BD Scherf, A Sonnino, JD Dargie (Eds.). Marker-Assisted Selection (MAS) in Crops, Livestock, Forestry and Fish: Current Status and the Way Forward. FAO, Rome, Italy, pp. 81-115.

14. Zhang Peng, D Xiao-Guang, X Qian, Z Shan Shan, A Dong, et al. (2008) Development of cassava biotechnology and functional genomics in China. In: A New Future for Cassava in Asia: Its Use as Food, Feed and Fuel to Benefit the Poor. Proc. $8^{\text {th }}$ Regional Workshop, held in Vientiane, Lao PDR, p. 48.

15. Taylor N, P Cavarriaga, K Raemakers, D Siritunga, Zhang P (2004) Development and application of transgenic technologies in cassava. Plant Molecular Biology 56(4): 671-688.

16. Tan SY, S Bowe (2008) Developing herbicide-tolerant crops from mutations. FAO/IAEA Intern. Symp. on Induced Mutations in Plants, held in Vienna, Austria, p. 134

17. Gupta VV (2012) Beneficial microorganisms for sustainable agriculture. Microbiol Australia 3: 113-115.

18. Bhattacharyya PN, Jha DK (2012) Plant growth-promoting rhizobacteria (PGPR): emergence in agriculture. World J Microbiol Biotechnol 28(4): $1327-1350$
19. Chaparro JM, Sheflin AM, Manter DK, Vivanco JM (2012) Manipulating the soil microbiome to increase soil health and plant fertility. Biol Fertil Soils 48: 489 -499.

20. Higa T, Parr JF (1994) Beneficial and Effective Microorganisms for a Sustainable Agriculture and Environment. International Nature Farming Research Center, Atami, Japan.

21. Horrigan L, Lawrence RS, Walker P (2002) How sustainable agriculture can address the environmental and human health harms of industrial agriculture. Environ Health Perspect 110(5): 445-456.

22. Johansson JF, Paul LR, Finlay RD (2004) Microbial interactions in the mycorrhizosphere and their significance for sustainable agriculture. FEMS Microbiol Ecol 48(1): 1-13

23. Wu F, Wang W, Ma Y, Liu Y, Ma X, et al. (2013) Prospect of beneficial microorganisms applied in potato cultivation for sustainable agriculture. Afr J Microbiol Res 7(20): 2150-2158.

24. Jones DL, Nguyen C, Finlay RD (2009) Carbon flow in the rhizosphere: carbon trading at the soil-root interface. Plant Soil 321(1): 5-33.

25. Raaijmakers JM, Paulitz TC, Steinberg C, Alabouvette C, Moënne Loccoz Y (2009) The rhizosphere: a playground and battlefield for soil borne pathogens and beneficial microorganisms. Plant Soil 321: 341-361.

26. Philippot L, Raaijmakers JM, Lemanceau P, Van der Putten WH (2013) Going back to the roots: the microbial ecology of the rhizosphere. Nat Rev Microbiol 11: 789-799.

27. Doran JW, Zeiss MR (2000) Soil health and sustainability: man-aging the biotic component of soil quality, Appl Soil Ecol 15(1): 3-11.

28. Kibblewhite M, Ritz K, Swift M (2008) Soil health in agricultural systems, Philos TR Soc B 363: 685-701.

29. Ritz, K, Black HI, Campbell CD, Harris JA, Wood C (2009) Selecting biological indicators for monitoring soils: a framework for balancing scientific and technical opinion to assist policy development. Ecological Indicators 9: 1212-1221.

30. Rutgers M, Van Wijnen H, Schouten A, Mulder C, Kuiten A, et al. (2012) A method to assess ecosystem services developed from soil attributes with stakeholders and data of four arable farms. Science of the Total Environment 415: 39-48.

31. Pindi PK, Satyanarayana SDV (2012) Liquid microbial consortium- a potential tool for sustainable soil health. J Biofertil Biopest 3: 1-4.

32. Dastager SG, Deepa CK, Pandey A (2010) Isolation and characterization of novel plant growth promoting Micrococcus sp NII-0909 and its interaction with cowpea. Plant Physiol Biochem 48: 987-992.

33. Ogbo FC (2010) Conversion of cassava wastes for biofertilizer production using phosphate solubilizing fungi. Bioresour Technol 101: 4120-4124.

34. Mohammadi K, Yousef Sohrabi Y (2012) Bacterial Biofertilizers for sustainable crop production: A review. J Agric Biol Sci 7(5): 307-316

35. Kogel KH, Franken P, Huckelhovenl R (2006) Endophyte or parasitewhat decides? Curr Opin Plant Biol 9: 358-363.

36. Paul D, Nair S (2008) Stress adaptations in a plant growth promoting Rhizobacterium (PGPR) with increasing salinity in the coastal agricultural soils. J Basic Microbiol 48: 1-7.

37. Van Loon LC, Bakker PA, Pieterse CM (1998) Systemic resistance induced by rhizosphere bacteria. Annu Rev Phytopathol 36: 453-483.

38. Van Oosten VR, Bodenhausen N, Reymond P, Van Pelt JA, Van Loon LC, et al. (2008) Differential effectiveness of microbial induced resistance against herbivorous insects in Arabidopsis. Mol Plant Microbe Interact 21(7): 919-930.

39. Lugtenberg B, Kamilova F (2009) Plant-Growth-Promoting Rhizobacteria. Annual Review of Microbiology 63: 541-556.

40. Vessey JK (2003) Plant growth promoting rhizobacteria as biofertilizers. Plant Soil 255(2): 571-586.

41. Jetiyanon K, Kloepper JW (2002) Mixtures of plant growth-promoting rhizo-bacteria for induction of systemic resistance against multiple plant diseases. Biol Control 24: 285-291. 
42. Segal E, Kushnir T, Mualem Y, Shani U (2008) Micro sensing of water dynamics and root distributions in sandy soils. Vadose Zone 7: 10181026.

43. Kim TK, Silk WK, Cheer AY (1999) A mathematical model for $\mathrm{pH}$ patterns in the rhizospheres of growth zones. Plant, Cell and Environment 22 1527-1538.

44. Beneduzi A, Ambrosini A, Passaglia LM (2012) Plant growth-promoting rhizobacteria (PGPR): their potential as antagonists and biocontrol agents. Gene Ther Mol Biol 35(4): 1044-1051.

45. Hiltner L (1904) Uber neuere Erfahrunger und Probleme auf dem Gebiete der Bodenbakteriologie unter besonderer Berucksichtigung der Grundungung und Brache. Arbeiten der Deutschen LandwirtschaftsGesellschaft 98: 59-78.

46. Dawkins R (1982) The extended phenotype: The gene as the unit of selection. Oxford University Press.

47. Lee S, Flores Encarnacion M, Contreras Zentella M, Garcia Flores L, Escamilla JE, et al. (2004) Indole-3-acetic acid biosynthesis is deficient in Gluconacetobacter diazotrophicus strains with mutations in cytochrome C biogenesis genes. J Bacteriol 186: 5384-5391.

48. Ramanandam C, Ravisankar G, Srihari D, (2008) Integrated Nutrient Management for Cassava Under Rainfed Conditions of Andhra Pradesh. Journal of Root Crops 34(2): 129-136.

49. Amanullahkhan MD (1997) Influence of fertilizer levels, intercropping and organic manures on the growth and yield of Cassava. Ph.D Thesis submitted to the Tamil Nadu Agricultural University, Coimbatore, India.

50. Zhuang X, Chen J, Shim H, Bai Z (2007) New advances in plant growthpromoting rhizobacteria for bioremediation. Environ Int 33(3): 406413.

51. Yadav RL, Prasad K, Dwivedi BS, Tomar RK, Singh AK (2000) Cropping systems. In G.B. Singh \& B.R. Sharma, eds. Fifty years of natural resource management research. New Delhi, Indian Council of Agricultural Research, pp. 411-446

52. Ano AO, Emehute JKU (2004) Complementary use of poultry manure and inorganic fertilizer in ginger production on an Ultisol of southeastern Nigeria. Niger Agric J 35: 50-59.

53. Kuzyakova Y, Friedelb JK, Stahra K (2000) Review of mechanisms and quantification of priming effects. Soil Biology \& Biochemistry 32: 14851498.

54. Kuzyakov Y, Blagodatskaya E (2015) Microbial hotspots and hot moments in soil: Concept \& review. Soil Biology and Biochemistry 83 184-199.

55. Cheng W, Parton WJ, Gonzalez-Meler Ma, Phillips R, Asao S, et al. (2014) Synthesis and modelling perspectives of rhizosphere priming. New Phytologist 201(1): 31-44

56. Vogel Hans Jörg, Stephan Bartke, Katrin Daedlow, Katharina Helming, Ingrid Kögel Knabner, et al. (2018) A systemic approach for modelling soil functions. SOIL 4: 83-92

57. Anon (2000) Fertiliser recommendations for Agricultural and Horticultural Crops. MAFF Reference Book RB209, 7th Edition, The Stationery Office, Norwich (ISBN 0 11243058-9), pp. 1-14.

58. Tan GH, Nordin MS, Kert TL, Napsiah AB, Jeffrey LSH (2009) Isolation of beneficial microbes from biofertilizer products. J Trop Agric and Fd Sc 37(1): 103-109.

59. Jeffries S, Gianinazzi S, Perotto S, Turnau K, Barea JM (2003) The contribution of arbuscular mucorhizal fungi in sustainable maintenance of plant health and soil fertility. Biol Fertil Soils 37(1): 1-16.

60. Bashan Y, G Holguin, LE de-Bashan (2004) Azospirillum-plant relationships: physiological, molecular,agricultural, and environmental advances (1997-2003). Canadian Journal of Microbiology 50(8): 521577.

61. Vassilev N, M Vassileva, R Azcon, A Medina (2001) Preparation of gelentrapped mycorrhizal inoculum in the presence or absence of Yarowia lipolytica. Biotechnology Letters 23(11): 907-909.
62. Smith RS (1992) Legume inoculant formulation and application. Canadian Journal of Microbiology 38(6): 485-492.

63. Muresu R, Sulas L, S Caredda (2003) "Legume-Rhizobium symbiosis: characteristics and prospects of inoculation" Rivoluzione Agronomica 37: 33-45.

64. Rhee KC (2001) Determination of Total Nitrogen. In Current Protocols in Food Analytical Chemistry; Wiley: New York, USA.

65. Olsen SR, Cole CV, Wantanable FS, Dean LA (1954) Estimation of available phosphorus in soil by extraction with Sodium bicarbonate. United State Dept of Agric CIRC, Washington DC, USA, 939.

66. Jackson ML (1967) Soil chemical analysis. Prentice Hall of India Pvt Ltd, New Delhi 1(1): 498.

67. Piper CS (1967) Soil and plant analysis. University of Adelaide, Adelaide, Australia.

68. McLeod S (1973) Studies on wet oxidation procedures for the determination of organic carbon in soils. CSIRO Division of Soils, Notes on Soil Techniques p: 73-79.

69. Lindsay WL, Norvell WA (1978) Development of DTPA soil test for zinc iron, manganese and copper Soil Science. Society of America Journal 42: 421-428.

70. Ano AO, Ikwelle MC (2000) On-farm evaluation of complementary use of poultry manure and inorganic fertilizer for cassava/maize/telfaria intercrop. Paper presented at the International Symposium on Balanced Nutrient Management Systems for the Moist Savanna and Humid Forest Zones of Africa, Cotonou, Benin, pp. 9 -12.

71. Mokwunye U (1978) Effect of farmyard manure and NPK fertilizers on crop yields and residual phosphorus in 24 years of cropping in Samaru. Nig J Soil Sci 12: 169-179.

72. Ano AO (1990) Potassium fixation, speciation, distribution and exchange thermodynamics in soils of eastern Nigeria. Ph D Thesis University of Ibadan, Ibadan, Nigeria, Agri Res \& Tech 2(1): 1-10.

73. Howeler RH (2014b) Sustainable Soil and Crop Management of Cassava in Asia - A Reference Manual. CIAT Publication No. 389. CIAT, Cali, Colombia, 280 p.

74. Howeler R, TM Aye (2014) Sustainable Management of Cassava in Asia. From Research to Practice. CIAT, The Nippon Foundation. Cali, Colombia, $148 \mathrm{p}$.

75. Adoa HM (2009) Growth, Yield and Quality of Cassava as Influenced by Terramend, Poultry Manure and Inorganic Fertilizer. Master's thesis; Department of Crop and Soil Sciences; Kwame Nkrumah University of Science and Technology, Kumasi, Ghana.

76. Adjei-Nsiah S, Issaka RN (2013) Farmers' agronomic and social evaluation of evaluation of productivity, yield and cooking quality in four cassava varieties. Am J Exp Agric 3: 165-174.

77. Luo, Xinglu C, Zhongyong P, Yinghua L, Cheng S, Zhifang (2008) Studies on the Effects of Bio-Organic Fertilizer on the Yield of Cassava. Chinese Agricultural Sci Bulletin 22(11): 202-206.

78. Pellet DM, El-Sharkawy MA (1997) Cassava varietal response to fertilization: growth dynamics and implications for cropping sustainability. Exp Agric 33: 353-365

79. Leo MV, Kabambe H (2014) Potential to increase cassava yields through cattle manure and fertilizer application: Results from Bunda College, Central Malawi. Lilongwe University of Agriculture and Natural Resources, pp: 1-45.

80. Agbaje GO, Akinlosotu TA (2004) Influence of NPK fertilizer on tuber yield of early and late-planted cassava in a forest alfisol of south-western Nigeria. Afr J Biotechol 3(10): 547-551.

81. Safo-Kantanka O, Asare E (1993) Factors Affecting properties of cassava. Proceedings of the 2nd National workshop on root and tuber crops and plantations CRI Annual Report pp: 107-118.

82. Cock JH (1976) Characteristics of high yielding cassava varieties. Expl Agric 12: 135-143. 
83. Glick BR (1995) The enhancement of plant growth by free-living bacteria. Can J Microbiol 41: 109-117.

84. Wholey DW, JH Cock (1974) Onset and rate of root bulking in cassava. Expl Agric 10(3): 197-198.

85. Connor DJ, J Palta (1981) Response of cassava to water shortage. III. Stomatal control of plant water status. Field Crops Res 4: 297-311.

86. FAO (2012) Save and Grow: A policy maker's guide to the sustainable intensification of smallholder crop production. Rome. pp. 98-150.

87. Ojeniyi SO, Samson AO, Odedina JN, Akinlana F (2012) Effect of different organic nutrient sources and two NPK rates on the performance and nutrient contents of a newly released cassava variety J Life Sci 6: 10031007.

88. Tisdale SL, Nelson WJ, Beaton JD (1993) Soil Fertility and Fertilizers. Macmillan Publishing Company. $4^{\text {th }}$ Edition. New York.

89. Kramer AW, Doane TA, Horwath WR, Kessel CV (2002) Combining fertilizer and organic inputs to synchronize $\mathrm{N}$ supply in alternative cropping systems in California. Agriculture, Ecosystem and Environment 91: 233-243.

90. Ayeni LS (2008) L.S. Integration of cocoa pod ash, poultry manure and NPK 20:10:10 fertilizer for soil fertility management -Incubation study. Continental Journal of Agronomy, Nigeria, pp 25-30.

91. Alves AC (2002) Cassava botany and physiology. In: R.J. Hillocks, J.M. Thresh and A.C. Bellotti (Eds.). Cassava: Biology, Production and Utilization. CABI Publishing, New York, USA, 56(4): 67-89.

92. Aslam M, SB Lowe, LA Hunt (1977) Effect of leaf age on photosynthesis and transpiration of cassava (Manihot esculenta). Can J Bot 55(17): 2288-2295.

93. El-Sharkawy MA (2006) International research on cassava photosynthesis, productivity, eco-physiology, and responses to environmental stresses in the tropics. Photosynthetica 44(4): 481-512.

94. El-Sharkawy MA, JH Cock (1987a) $\mathrm{C}_{3}-\mathrm{C}_{4}$ intermediate photosynthetic characteristics of cassava (Manihot esculenta Crantz). I. Gas exchange. Photosynth Res 12(3): 219-235.

95. Connor DJ, JH Cock (1981) Response of cassava to water shortage. II. Canopy dynamics. Field Crops Res 4: 285-296.

96. El-Sharkawy MA, Y Lopez, SM Bernal (2008) Genotypic variations in activities of phosphoenol pyruvate carboxylase and correlations with leaf photosynthetic characteristics and crop productivity of cassava grown in the lowland seasonally dry tropics. Photosynthetica 46(2): 238-247.

97. Cock JH, CA Luna, A Palma (2000) The trade-off between total harvestable production and concentration of the economically useful yield component: Cane tonnage and sugar content. Field Crops Research 67: $257-262$

98. Lenis JI, F Calle, G Jaramillo, JC Perez, H Ceballos, et al. (2006) Leaf retention and cassava productivity. Field Crops Res 95: 126-134.

99. Keating BA, JP Evenson, S Fukai (1982a) Environmental effects on growth and development of cassava (Manihot esculenta Crantz) I Crop development, Field Crops Research 5: 271-281.

100. Gomez KA, Gomez AA (1984) Statistical procedure for agricultural research. John Wileyand Sons, USA, pp. 104-115.

101. Pellet D, El Sharkawy MA (1993b) Cassava varietal response to phosphorus fertilization. II. Phosphorus uptake and use efficiency Field Crops Research 35: 13-20.

102. Howeler RH, E Sieverding (1983) Potential and limitations of mycorrhizal inoculation illustrated by experiments with field grown cassava. Plant and Soil 75: 245-261.

\section{FAOSTAT (2011)}

104. Tian Yinong (2010) A new future for cassava in animal feed and biofuel in China.

105. Jin Shuren (2001) Production and use of modified starch and starch derivatives in China.
106. Jin, Shuren (2000) The current situation and prospects for further development of China's sorbitol industry. In: RH Howeler, CG Oates, GM 0 Brien (Eds.). Cassava, Starch and Starch Derivatives. Proc Intern Symp, held in Nanning, Guangxi, China, pp. 32-36.

107. Wang, Xiaodong, Guo Xuan, SK Rakshit (2000) Study of lactic acid fermentation with Lactobacillus amylovarus using cassava starch. In: RH Howeler, CG Oates, GM O Brien (Eds), Cassava, Starch and Starch Derivatives. Proc Intern Symp, held in Nanning, Guangxi, China, pp. 198-201.

108. Sriroth K, R Chollakup, K Piyachomkwan, CG Oates (2001) Biodegradable plastics from cassava starch in Thailand. In: RH Howeler and SL Tan (Eds). Cassava's Potential in Asia in the $21^{\text {st }}$ Century: Present Situation and Future Research and Development Needs. Proc. $6^{\text {th }}$ Regional Workshop, held in Ho Chi Minh city, Vietnam, pp. 538-552.

109. Yomeni MO, Akoroda MO, Dixon AGO (2010) Cassava (Manihot esculenta crantz) stems quality for root production effectiveness Proc. $11^{\text {th }}$ ISTRC-AB Symp. Kinshasa, DR Congo.

110. Adesemoye AO, Torbert HA, Kloepper JW (2010) Increased plant uptake of nitrogen from $15 \mathrm{~N}$-depleted fertilizer using plant growthpromoting rhizobacteria. App Soil Ecol 46(1): 54-58.

111. Angelov MN, J Sun, GT Byrd, RH Brown, CC Black (1993) Novel characteristics of cassava, Manihot esculenta Crantz, a reputed $\mathrm{C}_{3}-\mathrm{C}_{4}$ intermediate photosynthesis species. Photosynthesis Research 38(1): 61-72.

112. Artursson V, Finlay RD, Jansson JK (2006) Interactions between arbuscular mycorrhizal fungi and bacteria and their potential for stimulating plant growth. Environ Microbiol 8(1): 1-10.

113. Bahat-Samet E, Castro-Sowinski S, Okon Y (2004) Arabinose content of extracellular polysaccharide plays a role in cell aggregation of Azospirillum brasilense. FEMS Microbiol Lett 237(2): 195-203.

114. Banat IM, Franzetti A, Gandolfi I, Bestetti G, Martinotti MG, et al. (2010) Microbial biosurfactants production, applications and future potential. Applied Microbiology and Biotechnology 87(2):427-444.

115. Chanway CP, Holl FB (1993) First year yield performance of spruce seedlings inoculated with plant growth promoting rhizobacter. Can J Microbiol 39(11): 1084-1088

116. Compant, Setal (2005) Use of plant growth-promoting bacteria for biocontrol of plant diseases: principles, mechanisms of action and future prospects. Appl Environ Microbiol 71(9): 4951-4959.

117. Cotter PD, Hill C, Ross RP (2005) Bacteriocins: developing innate immunity for food. Nature Review Microbiology 3: 777-788.

118. Crawford DL, Lynch JM, Whipps JM, Ousley MA (1993) Isolation and characterization of actinomycetes antagonists of a fungal root pathogen. Appl Environ Microbiol 59: 3899 -3905.

119. De Bello F, Lavorel S, Diaz S, Harrington R, Cornelissen JHC (2010) Towards an assessment of multiple ecosystem processes and services via functional traits. Biodiversity Conservation 19(10): 873-2893.

120. Desai JD, Banat IM (1997) Microbial production of biosurfactants and their commercial potential. Microbiology and Molecular Biology Reviews 61(1): 47-64

121. El-Sharkawy MA, JH Cock (1986) The humidity factor in stomatal control and its effect on crop productivity. In: R Marcelle and M. Van Pouchke (Eds.), Biological Control of Photosynthesis. Martinus Nijhoff Publishers, the Netherlands, pp. 187-198.

122. Ergen NZ, Budak H (2009) Sequencing over 13000 expressed sequence tags from six subtractive cDNA libraries of wild and modern wheats following slow drought stress. Plant Cell Environ 32(3):220-236.

123. Glick BR, Cheng Z, Czarny J, Duan J (2007) Promotion of plant growth by ACC deaminase containing soil bacteria. Eur J Plant Pathol 119: 329-39.

124. Hans-Jörg Vogel, Stephan Bartke, Katrin Daedlow, Katharina Helming, Ingrid Kögel-Knabner, et al. (2018) A systemic approach for modeling soil functions SOIL 4: 83-92.

125. Howeler, SL Tan (Eds.) (2000) Cassava's Potential in Asia in the $21^{\text {st }}$ Century: Present Situation and Future Research and Development 
Needs. Proc $6^{\text {th }}$ Regional Workshop, held in Ho Chi Minh city, Vietnam, pp. 553-563.

126. Howeler RH (Ed.) (2008) A new Future for Cassava in Asia: Its Use as Food, Feed and Fuel to Benefit the Poor. Proc $8^{\text {th }}$ Regional Workshop, held in Vientiane, Lao PDR, pp. 120-137

127. Howeler RH (1985a) Mineral nutrition and fertilization of cassava. In Cassava; Research, Production and Utilization. UNDP-CIAT Cassava Program, Cali, Colombia, pp. 249-320.

128. Jadhav M, Kalme S, Tamboli D, Govindwar S (2011) Rhamnolipid from Pseudomonas desmolyticum NCIM-2112 and its role in the degradation of Brown. Journal of Basic Microbiology 51(4): 1-12.

129. Jensen HL (1965) Non-symbiotic nitrogen fixation. In: Soil nitrogen (Eds.: WV Bartholomew and FE Clark). American Society of Agronomy 10: 440-485.

130. Keiblinger KM, Wilhartitz IC, Schneider T, Roschitzki B, Schmid E, et al. (2012) Soil metaproteomics: comparative evaluation of protein extraction protocols. Soil Biol Biochem 54(15-10): 14-24.

131. Khan N, Bano A, Babar MA (2017) The root growth of wheat plants, the water conservation and fertility status of sandy soils influenced by plant growth promoting rhizobacteria. Symbiosis 72(3): 195-205.

132. Khosravi A, Zarei M, Ronaghi A (2018) Effect of PGPR, phosphate sources and vermicompost on growth and nutrients uptake by lettuce in a calcareous soil. J Plant Nutr 41(1): 80-89.

133. Kloeppe JW, Rodriguez-Kabana R, Zehnder AW, Murphy JF, Sikora E, et al. (1999) Plant root-bacterial interactions in biological control of soil borne diseases and potential extension to systemic and foliar diseases. Australas Plant Pathol 28(1): 21-26.

134. Kohler J, Caravaca F, Carrasco L, Roldan A (2007) Interactions between a plant growth-promoting rhizobacterium, an AM fungus and a phosphate-solubilising fungus in the rhizosphere of Lactuca sativa. Appl Soil Ecol 35(3): 480-487.

135. Kumari ME, Gopal AV, Lakshmipathy R (2018) Effect of stress tolerant plant growth promoting Rhizobacteria on growth of Blackgram under stress condition. Int J Curr Microbiol App Sci 7(1): 1479-1487.

136. Levy N, Baror Y, Magdassi S (1990) Colloids surfactants. Research Journal of Pharmaceutical, Biological and Chemical Science 48: 337 349

137. Lugtenberg B, Kamilova F (2009) Plant-growth-promoting rhizobacteria. Annu Rev Microbiol 63: 541-556.

138. Maheshwari DK, Annapurna K (2017) Endophytes: Crop Productivity and Protection, Sustainable Development and Biodiversity 16, Springer International Publishing AG Manihot esculenta Crantz, a reputed C3 C4 intermediate photosynthesis species. Photosynth Res 38: 61-72.

139. Morris AC, Djordjevic MA (2006) The rhizobium leguminosarum biovar trifolii ANU794 includes novel developmental responses on the subterranean clover cultivar Woogenellup. Mol Plant Microbe Interact 19: 471-479.

140. Nerurkar AS, Hingurao KS, Suthar HG (2009) Bioemulsfiers from marine microorganisms. Journal of Science Industrial Research, 68 273-277.

141. Pal S, Manna A, Paul AK (1999) Production of poly ( $\hat{I}^{2}$-hydroxybutyric acid) and exopolysaccharide by Azotobacter beijerinckii WDN-01 World J Microbiol Biotechnol 15(1) :116

142. Salazar N, Prieto A, Leal JA, Mayo B, Bada Gancedo JC, et al. (2009) Production of exopolysaccharides by lactobacillus and Bifidobacterium strains of human origin, and metabolic activity of the producing bacteria in milk. J Dairy Sci 92(9): 4158-4168.

143. Schmidt FR (2005) "Optimization and scale up of industrial fermentation processes" Appl Microbiol Biotechnol 68(4): 425-435.

144. Seghers D, Wittebolle L, Top EM, VerstraeteW, Siciliano SD (2006) Impact of agricultural practices on the Zea mays L. endophytic community. Appl Environ Microbiol 70(3): 1475-1482.

145. Sharma A, Thakur DR, Kanwar S, Chandla VK (2013) Diversity of entomopathogenic bacteria associated with the white grub, Brahmina coriacea. J Pest Sci 86(2): 261-273.
146. Shivaji S, Shyamala Rao N, Saisree L, Sheth V, Reddy GS, et al. (1989) Isolation and identification of Pseudomonas species from Schirmacher Oasis, Antarctica. Appl Environ Microbiol 55(3): 767-770.

147. Sharma AK, Govil CM (1988) After effect of seed treatment with growth substances on elongation and histology of hypocotyls in Citrulluslanatus Var. istulosus. Journal of the Indian Botanical Society 67: 6164 .

148. Somers E, Vanderleyden J, Srinivasan M (2004) Rhizosphere bacteria signalling: a love parade beneath our feet. Crit Rev Microbiol 30(4): 205-240.

149. Sood G, Kaushal R, Chauhan A, Gupta S (2018) Effect of conjoint application of indigenous PGPR and chemical fertilizers on productivity of maize (Zea mays L.) under mid hills of Himachal Pradesh. J Plant Nutr 41(3): 297-303.

150. Subbaiah BV, Asija GL (1956) A rapid procedure for the estimation of available nitrogen in soil Curr Sci 25(8): 259-260.

151. K Susan John, CS Ravindran J George, Manikantan N, Suja G (2005) Potassium: A Key Nutrient for High Tuber Yield and Better Tuber Quality in Cassava.

152. Sutyak KE, Wirawan RE, Aroutcheva AA, Chiindas ML (2008) Isolation of the Bacillus subtilis antimicrobial peptide subtilosin from the dairy product derived Bacillus amyliquefaceiens. J Appl Microbiol 104(4): 1067-1074

153. Thai Phien, Nguyen Cong Vinh (1998) Nutrient management for cassava-based cropping systems in northern Vietnam. In: RH Howeler (Ed), Cassava Breeding, Agronomy and Farmer Participatory Research in Asia. Proc. $5^{\text {th }}$ Regional Workshop, held in Danzhou, Hainan, China, pp. 268-279.

154. Thai Tapioca Flour Industries Trade Association (TTFITA) (2000) $24^{\text {th }}$ Anniversary, Bangkok, Thailand, pp. 130

155. Tohme, Fregene M (2001) Simple sequence repeat (SSR) markers survey of the cassava (Manihot esculenta Crantz) genome: towards an SSR-based molecular genetic map of cassava. Theor Appl Genetics 102(1): 21-31.

156. Velusamy P, JE Immanuel, SS Gnanamanickam, LS Tomashow (2006) Biological control of rice bacterial blight by plant associated bacteria producing 2,4-diacetylphloroglucinol. Can J Microbiol 52(1): 56-65.

157. Vidyarthi AS, M Desrosiers, RD Tyagi, JR Valero (2000) Foam control in biopesticide production from sewage sludge. Journal of Industrial Microbiology and Biotechnology 25(2): 86-92.

158. Vyas P, Gulati A (2009) Organic acid production in vitro and plant growth promotion in maize under controlled environment by phosphate- solubilizing fluorescent pseudomonas. BMC Microbiol 9(1): 174

159. Wang CJ, Yang W, Wang C, Gu C, Niu D, et al. (2012) Induction of drought tolerance in cucumber plants by a consortium of three plant growthpromoting rhizobacterium strains. PLoS One 7(12): e52565.

160. Wu SC, Cao ZH, Li ZG, Cheung KC, Wong MH (2005a) Effects of biofertilizer containing $\mathrm{N}$-fixer, $\mathrm{P}$ and $\mathrm{K}$ solubilizers and $\mathrm{AM}$ fungi on maize growth: a greenhouse trial. Geoderma 125(1-2): 155 -166.

161. Wu T, Malinverni J, Ruiz N, Kim S, Silhavy TJ, et al. (2005b) Identification of a multicomponent complex required for outer membrane biogenesis in Escherichia coli. Cell 121(2): 235-245.

162. Xie H, Pasternak JJ, Glick BR (1996) Isolation and characterization of mutants of the plant growth promoting rhizobacterium Pseudomonas putida GR12-2 that overproduce indoleacetic acid. Curr Microbial 32(2): 67-71.

163. Yadav AN, Verma P, Sachan SG, Kaushik R, Saxena AK (2015e) Microbes mediated alleviation of cold stress for growth and yield of wheat (Triticum aestivum L.). In: Proceeding of international conference on "Low Temperature Science and Biotechnological Advances".

164. Yumoto I, Nakamura A, Iwata H, Kojima K, Kusumoto K, et al. (2002) Dietzia psychralcaliphila sp. nov., a novel, facultatively psychrophilic alkaliphile that grows on hydrocarbons. Int J Syst Evol Microbiol 52(Pt 1): $85-90$

Citation: Ayodele A Otaiku, Mmom PC, Ano AO. Growth, Biofertilizer Impacts on Cassava (Manihot Esculenta Crantz) Rhizosphere: Crop Yield and Growth Components, Igbariam, Nigeria - Paper 1. World J Agri \& Soil Sci. 3(5): 2019. WJASS.MS.ID.000575. 